\title{
HILGARDIA
}

A Journal of Agricultural Science Published by the California Agricultural Experiment Station

\section{RELATIONSHIPS OF THE STRAWBERRY VIRUSES OF ENGLAND AND CALIFORNIA}

NORMAN W. FRAZIER

and

ADRIAN F. POSNETTE

UNIVERSITY OF CALIFORNIA - BERKELEY, CALIFORNIA 
A comparison made at the East Malling Research Station of the strawberry viruses known in California with those of England indicated that the curly-dwarf mottle, mottle, mild yellow-edge, latent-A, and crinkle viruses occurred in both England and California; the rusty-leaf mottle, lesion-B, vein chlorosis, green petal, mosaic, raspberry yellow dwarf, and raspberry ring spot viruses were not known in California; the vein banding, yellow vein banding, latent-B, lesion-A, and western aster yellows viruses were not found in England; while the leaf-curl virus was known only in plants in the East Malling Research Station glasshouse.

The viruses studied could be provisionally grouped according to their symptoms and vector-host relationships, but the evidence obtained did not clearly define the level of relationships among the viruses within the groups.

Comparative tests suggested that the incubation period for development of symptoms in the plant and the rate of virus loss by vectors are useful characters in distinguishing between strawberry viruses, but the acquisition threshold period and rate of virus acquisition appeared to be less useful.

Rusty-leaf mottle, curly-dwarf mottle, yellow vein banding, lesion-A, and lesion-B are newly described viruses with aphid vectors.

Pentatrichopus thomasi and $P$. thomasi ssp. jacobi are reported to be vectors of strawberry viruses while Amphorophora rubi was demonstrated to be a vector of the leaf-curl virus.

Duchesnea indica and Nicotiana bigelovii are newly determined experimental and natural hosts respectively of the western aster yellows virus. 


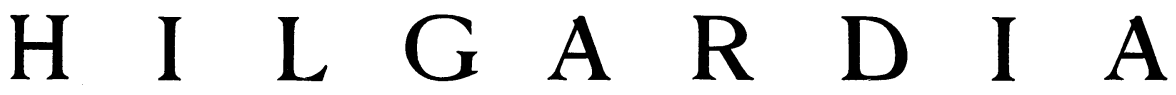

A Journal of Agricultural Science Published by

the California Agricultural Experiment Station

\section{RELATIONSHIPS OF THE STRAWBERRY VIRUSES OF ENGLAND AND CALIFORNIA ${ }^{1}$}

\section{NORMAN W. FRAZIER ${ }^{2}$ and ADRIAN F. POSNETTE ${ }^{3}$}

\section{INTRODUCTION}

MOST vIRUSEs which are known to infect strawberries under natural conditions can be transmitted only by aphid vectors or by graft and are not known to infect hosts other than species of Fragaria or Potentilla. Two viruses, aster yellows and green petal, are transmitted by leafhoppers and both occur more commonly in other hosts than in strawberry. Three viruses, tobaceo necrosis, raspberry yellow dwarf, and raspberry ring spot are soilborne, transmissible by mechanical inoculation, and are known to naturally infect other hosts.

Strawberry yellows, the first disease of strawberries proved to be of virus nature, was reported by Horne in 1922." It was first called yellows by Plakidas (1926), but later (1927) he used the name "Xanthosis" and demonstrated that it could be transmitted by the strawberry aphid, Pentatrichopus (=Capitophorus = Myzus) fragaefolii (Ckll.), to Banner variety seedling test plants. He used a minimum test feeding period of seven days. Symptoms developed on the test plants in two to five weeks after inoculation.

Strawberry witches'-broom was described in Oregon on the Marshall variety by Zeller (1927). He reported transmission of the virus by strawberry aphids fed on diseased plants for eight days and then transferred to Marshall test plants.

Strawberry crinkle was reported on the Marshall strawberry in Oregon by Zeller and Vaughan (1932). Vaughan (1933) transmitted the disease with strawberry aphids to Marshall test plants. Zeller (1933) reported an incubation period of from 12 to 15 days in Marshall test plants. He also recognized that crinkle probably was composed of two separable components-one causing a "mild crinkle"-but he did not indicate their symptom differences.

Stunt disease was also described on the Marshall strawberry in Oregon

${ }^{1}$ Received for publication November 8, 1957.

${ }^{2}$ Department of Entomology, University of California, Berkeley. On leave at the East Malling Research Station, October, 1955, to September, 1956.

${ }^{3}$ Plant Pathology Section, East Malling Research Station, England.

"See "Literature Cited" for citations referred to in the text by author and date. 
by Zeller and Weaver (1941) who reported transmission by the strawberry aphid but gave no experimental details.

Strawberry leaf roll was reported from Ontario and New York (Berkeley and Plakidas, 1942). It was transmitted by grafting from the variety Premier to Fragaria virginiana Duchesne and from diseased to healthy plants of two seedling clones. Insect transmission was not attempted.

In their investigations of strawberry viruses, English workers contributed several advances in technique: Harris (1932) and Harris and King (1942) developed a useful method of grafting; Harris and King (1942) discovered that the wild strawberry Fragaria vesca L. was very sensitive to strawberry viruses and could be used to great advantage as an indicator plant; and Prentice and Harris (1946) demonstrated that use could be made of vectorvirus relationships to separate components of strawberry virus complexes.

In England, Harris (1933) applied the name yellow-edge to a disease of the variety Royal Sovereign and emphasized the close similarity of the symptoms to those caused by the yellows disease of the Marshall variety in California. Prentice (1948) used differential virus-vector relationships to demonstrate that yellow-edge was a complex resulting from infection with two viruses. One virus, called virus 1 , persisted for only about three hours in the vector while the second, called virus 2 (mild yellow-edge virus), persisted in the vector for several days.

Crinkle was first recorded in England on Royal Sovereign plants by Ogilvie, Swarbrick, and Thompson (1934) who considered the symptoms to be identical to those of the Oregon crinkle disease. Harris $(1937 a, 1937 b)$ confirmed the similarity of the diseases in England and Oregon, proved the virus nature by graft transmission, pointed out that symptoms were predominantly of two types, which he designated as mild crinkle and severe crinkle, and inferred the interaction of two viruses. Prentice and Harris (1946) isolated a virus which persisted about three hours in the strawberry aphid, and they concluded that this was probably the mild crinkle virus. Prentice (1948) designated the isolate as virus 1, and later (1952) proposed the name "strawberry mottle," stating that he considered the virus distinct from that causing mild crinkle. He also demonstrated that a form of severe crinkle could be caused by a complex of virus 1 with a long-persistent type of virus designated as virus 3 (1949), which he later (1952) named strawberry crinkle.

Vein chlorosis virus (virus 4) and leaf-curl virus (virus 5) were described by Prentice (1952) who transmitted the former by grafting but not by the strawberry aphid; virus 5 was isolated by means of strawberry aphids from a Fairfax plant that originated in North America.

Green petal was described by Posnette (1953b) on the Auchincruive Climax and other varieties in England. The virus was transmitted by grafting but not by the strawberry aphid and the pattern of field spread suggested an alternate host and a vector with different habits from those of the strawberry aphid. Frazier and Posnette (1956) found that two species of leafhoppers could transmit the virus and that the disease was common in both red and white clover in the field.

Strawberry mosaic was described by Posnette (1956) as a disease with 
somewhat variable symptoms and of rare occurrence in England. It was transmitted by grafting but not by the strawberry aphid although the aphids did transmit both mild crinkle and crinkle from plants having mosaic.

Two soil-borne raspberry viruses have been very recently associated with strawberries by Scottish workers. Raspberry yellow dwarf virus has been demonstrated by Harrison (1958) to be the cause of a crinkle-like disease of strawberry, and Lister (1958) recovered the raspberry ring spot virus from naturally infected strawberry plants in which symptoms were similar to those caused by the yellow dwarf virus.

In recent years additional viruses have been associated with strawberries in North America. Plakidas (1951) reported on a chlorotic phyllody disease in Louisiana with symptoms suggestive of aster yellows infection. Frazier and Thomas (1953) demonstrated that a disease of strawberry in California, with symptoms similar to those of chlorotic phyllody in Louisiana, was caused by the Western aster yellows virus. Similar diseases were noted in Arkansas by Smith (1954) and in Nova Scotia by Gourley (1955) who considered the symptoms of the Nova Scotia disease to resemble closely those of the strawberry green petal disease of England. Fulton (1957) related the cause of the Arkansas disease to the aster yellows virus.

Fulton (1952) reported tobacco necrosis virus to be rarely associated with strawberries under natural conditions but very commonly so in glasshouses. Frazier (1955a) reported that the virus did not become systemic in strawberry plants and that its presence did not appear to alter the expression of symptoms caused by other viruses in strawberry.

Two strains of strawberry latent virus were described by Frazier (1953). Strain A was found in plants of the East Malling indicator clone of Fragaria vesca, while the more severe strain B was isolated from naturally infected plants of the native woodland strawberry $F$. vesca var. californica C\&S. The viruses were transmitted only by grafting; no symptoms were recognized and the viruses could be detected only by introducing a second virus (i.e., strawberry mottle). The resulting complex produced symptoms more severe than those produced by the second virus alone.

Strawberry vein banding (Frazier, 1955b) was isolated from Marshall and other strawberry varieties in California. In Marshall the complex of vein banding and latent viruses was equated with the "mild crinkle" of Zeller (1933), and thought to be related to the strawberry leaf-curl of Prentice (1952). The virus was transmitted by grafting, by dodder (Cuscuta subinclusa Dur. and Hilg.), and by the aphids Amphorophora rubi (Kalt.), Macrosiphum pelargonii (Kalt.), Myzus ornatus (Laing.) and the strawberry aphid Pentatrichopus fragaefolii (Ckll.); in the latter aphid the virus persisted as long as eight hours, but usually less than five hours.

Thomas (1949) used $F$. vesca var. californica C\&S. as his indicator plant, which he infected by grafting to Marshall plants from the Pacific Coast and from the eastern United States. The virus from the Pacific Coast plants caused symptoms which were termed "mottle" while those induced by virus from the eastern plants were called "droop." He considered the mottle virus to be a component of yellows (Xanthosis).

Demaree and Marcus (1951) in Maryland described two types of symp- 
toms that developed on plants of the East Malling $F$. vesca indicator clone after inoculation by grafting or by aphids. The authors designated them as types 1 and 2 but did not determine whether they were caused by single viruses or by complexes. They believed type 1 to be similar to the yellows and crinkle of the Pacific Coast and identified type 2 symptoms as those of the droop virus of Thomas (1949). These types were elucidated by McGrew (1956) who designated a new strawberry virus as latent-C virus. He produced the type 1 symptoms by combining a mild strain of strawberry mottle virus with either strawberry latent-A virus or with latent- $C$ virus. The type 2 symptoms were produced when latent-C virus was combined with strawberry latent-A virus.

In British Columbia, Mellor and Fitzpatrick (1951) used strawberry aphids to isolate two virus components of yellows from Marshall and British Sovereign plants. One component was persistent and the other not persistent in the aphid vector, and on the basis of symptoms and vector-virus relationships, the components were respectively analogous to Prentice's virus 2 and to Prentice and Harris virus 1, but neither component appeared to correspond exactly to the previously described viruses.

The comparison of strawberry viruses in different geographical regions has been difficult. Because the strawberry viruses are not mechanically transmissible and infect few species there are few characters upon which to base descriptions or comparisons, the principal ones of which are symptoms and vector-virus-plant relationships. Fitzpatrick and Mellor (1951) have pointed out that the strawberry virus diseases usually have been studied by different methods independently in the particular localities where they occurred on different varieties of strawberries. Other factors contributing to tenuous comparisons include the great variability of symptoms of some of the viruses or virus groups, the difficulty of obtaining satisfactory vector transmission of many of them, and the fact that most of the described diseases were caused by virus complexes.

The investigations described in this paper were carried out at the East Malling Research Station to determine: (1) the relationships of the strawberry viruses previously described and currently under investigation at the East Malling Research Station with strawberry viruses known in California, and (2) the value of certain tests of vector-virus-plant relationships in characterizing strawberry viruses.

\section{MATERIALS AND METHODS}

The materials used and methods followed at East Malling and Berkeley were as comparable as possible, the experimental design of certain comparative tests being identical.

Four Fragaria vesca indicator plants were used: (1) Alpine, a seedpropagated, runnerless strain of a red-fruited Alpine variety (Frazier, 1955) ; (2) UC-1, a runnering clone originating at Berkeley as a fortuitous seedling of an open pollinated Alpine, the pollen parent thought probably to have been an East Malling clone plant; (3) EMC, the East Malling clone universally infected with latent-A virus; and (4) EMS-1, a clone originat. ing at East Malling from an EMC selfed seedling. 
Alpine was used as the principal indicator for the comparison and description of symptoms caused by viruses separated by aphids from latent-A virus. The symptoms expressed by plants of the UC-1 clone were similar to those in Alpine which gave, however, better differentiation of the mottle virus strains and of the vein banding and yellow leaf-curl viruses. Symptoms in UC-1 gave the best differentiation of the crinkle viruses or strains, while mild yellow-edge seemed to be expressed equally well by both indicator plants. EMS-1 has not been tested sufficiently to determine its comparative value as an indicator. Symptoms expressed by EMC are caused by a virus complex including latent-A virus and may be different from the symptoms caused by the given second virus alone.

At East Malling a wide range of differing isolates in EMC, Royal Sovereign, and other varieties was available, including the type viruses previously described at the Research Station. Two sources of known viruses from California were also available for direct comparison. At Berkeley, virus sources have included commercial and wild plants, some of which originated in other states and in England.

The strawberry aphid, Pentatrichopus fragaefolii (Ckll.), was used in all tests at East Malling. Stock colonies were maintained principally on Shasta variety plants; for unknown reasons difficulty was experienced in rearing the aphids on virus-free indicator plants. Noninfective aphids were secured by transferring adult aphids to Alpine plants and collecting the nymphs which were produced there over a period not exceeding 48 hours. Such one- or two-day-old nymphs were used to initiate most tests. In a few tests the adult apterous aphids were used after they had fed on the Alpine plants (which provided a test of the noninfectivity of the aphids), while in several tests stock aphids were used directly from the colony plant.

Two species of strawberry aphids have been used at Berkeley: P. fragaefolii, $P$. thomasi Ris Lambers, and $P$. thomasi ssp. jacobi Ris Lambers (Hille Ris Lambers, 1953). Because of individual and colony characteristics and at least equal if not superior efficiency in virus transmission, $P$. $t$. jacobi has been used in recent years almost to the exclusion of the other aphids. Except where specifically noted to the contrary, jacobi was the vector used at Berkeley for the aphid tests reported here. Colonies of noninfective aphids were maintained on Alpine plants and were transferred with a brush to the youngest developing leaf of test plants which were caged only if the test feeding periods were eight hours or longer.

To determine the acquisition threshold period of the virus, several viruses at Berkeley were subjected to a standard test in which noninfective aphids were placed on the virus source plant and allowed to feed for periods of $30,40,50,60,90$, and 120 minutes. At the end of each period groups of three aphids were transferred to each Alpine test plant where they were allowed to complete a test feeding period of at least 6 but normally about 20 hours.

A standard test was used at both Berkeley and East Malling to determine the period of virus retention and the rate of loss of different viruses in the aphid vector. Previously noninfective aphids were given an acquisition feeding period of 20 hours on a virus source and then transferred in groups 
of three aphids at hourly intervals to eight successive Alpine test plants. The aphids normally remained on the last plant up to 16 hours.

The environmental conditions at East Malling and Berkeley differed. Because of the more northerly latitude of East Malling, the length of day was shorter in winter and longer in summer than at Berkeley. Due to differences in weather and glasshouses, daily glasshouse temperatures fluctuated more with a lower average minimum at East Malling than at Berkeley and light intensity was less uniform. Aphid tests were carried out in a glasshouse compartment subject to irregular changes of light and temperature at East Malling while at Berkeley aphid transfers and test feeding periods were completed in a laboratory at nearly uniform room temperature and northern light exposure.

\section{STRAWBERRY MOTTLE VIRUS}

The name mottle was first used by Thomas (1949) to designate symptoms on $F$. vesca californica which can be caused by mottle virus alone or in combination with either strawberry latent-A or latent-B viruses. The symptoms of strawberry mottle described by Prentice (1952) are now known to have been caused by a complex of mottle and latent-A viruses. Previously, Prentice (1948) had called this complex virus 1 and earlier, with Harris (1946), had tentatively equated it with the mild crinkle virus of Harris and King (1942). It is now recognized that mild crinkle can be caused by other virus complexes similar to, and in addition to, the virus 1 complex. The aphid transmitted mottle virus of Prentice and Harris (virus 1) is considered here to represent the type form of strawberry mottle virus.

Prentice and Harris (1946) showed that the virus could be transmitted by strawberry aphids after acquisition feeding periods of one hour, that it did not usually persist in the aphid longer than three hours, and that prefasting of the aphids appeared not to affect transmission. Symptoms varied in severity and could be classified as mild or severe. Prentice (1948) reported that an incubation period of between two and three weeks was required for the appearance of symptoms on EMC plants.

For purposes of the present study at the East Malling Research Station 16 plants, nearly all EMC, were selected as sources of mottle virus. They were chosen because they were infected with isolates with which tests had been carried out in previous years and which represented an extreme range of mild crinkle symptoms. Included among them were Prentice's mild and severe mottle types and the leaf burn or $\mathrm{X}$ virus of Posnette, Cropley, and Ellenberger (1953) which Posnette (1953a) reported to be more rapidly inactivated by heat therapy than is mild crinkle virus. In addition, a plant of the Northwest variety from the Pacific Coast yielded a mottle virus, and one isolate (mottle isolate No. 2) used extensively at Berkeley was secured for comparative testing at East Malling after it became obvious that some of the mottle virus forms at East Malling were nearly identical with it.

Virus from each of the 16 East Malling source plants was transmitted by strawberry aphids to Alpine and UC-1 test plants. Rusty-leaf, a new form of mottle virus, was recovered from one of the source plants which 
showed veinlet clearing (Posnette, 1952) and which had been originally infected by Acyrthosiphon malvae ssp. rogersii aphids from a yellow-edge diseased Royal Sovereign plant. Another source plant yielded curly-dwarf which is likewise a new form of mottle virus. Typical mottle virus was transmitted from 11 source plants while from three plants both the typical mottle and curly-dwarf forms were recovered.

At Berkeley, isolates of the typical and curly-dwarf forms of mottle virus have both been obtained from a range of cultivated and wild strawberry plants from a number of localities.

\section{Symptoms}

Strawberry mottle virus includes a large number of stable variants causing symptoms which intergrade; those studied were similar qualitatively but quantitatively they appeared to represent three groups of forms. The vector-virus-plant relationships were consistent among representative isolates within each group but differed between the groups. The significance of the differences cannot at present be evaluated nor has it been established that an intergradation of the vector-virus-plant relationships similar to that of the symptoms would not be demonstrated if a sufficient number of isolates were tested. The variants of the three groups represent the type or mottle, the curly-dwarf and the rusty-leaf forms of strawberry mottle virus. There was symptom variation within the first two groups and intergradation between all three so that single isolates could not be clearly differentiated descriptively; new isolates could not with certainty be identified with previous isolates. Some isolates never varied during subsequent transfers, while from others one or more milder variants occurred which were subsequently stable during subtransfers; these segregates always caused milder symptoms than those on the source plant.

Mottle. The symptoms typical of mottle virus may be grouped into faint, mild, intermediate, and severe mottle, the names merely indicating the relative degree of expression of what otherwise were similar symptoms.

The faint, mild, and intermediate variants of mottle were characterized in Alpine plants by mottling formed by finely cleared net veins, interveinal chlorosis or spotting distributed more or less uniformly over the entire leaf with very little leaf distortion (Figs. 1A-C) ${ }^{5}$ and an absence of abnormal crown proliferation or severe stunting (Fig. 2, center and right). The first symptoms consisted of veinlet clearing (Fig. 3, left), delayed or unequal unfolding of leaflets, and slight to severe epinasty of the youngest leaf (Fig. 5). An epinastic shock effect, sometimes accompanied by necrosis of young leaves (Fig. 4) and tips of stolons occurred in UC-1 and EMC plants carrying latent-A virus.

Symptoms in Alpine infected with severe mottle virus differed from those caused by the above three milder forms by the absence of chlorotic spotting; all veins were finely cleared, many fused and the leaf color was a nearly uniform, nonmottled, chlorotic green (Fig. 1,D). There was slight crown proliferation; leaves were small and frequently distorted; and petioles were short, twisted or curled. The alteration in leaf shape was rather uniform

${ }^{5}$ Figures 1 to 26 , inclusive, follow "Literature Cited," at the end of the publication. 
for all leaflets of a given leaf. Initial symptoms of infection were severe with outward rolling of leaflets and epinasty of the petiole of the first, and often the second, leaf to show symptoms; vein. clearing was so severe on the first or second leaf as to appear like a general chlorosis of the entire leaf (Fig. 6). Necrosis sometimes occurred but less commonly than with curly-dwarf infection. On UC-1 plants, stolons, when formed, were thin and weak. A severe epinastic shock effect, accompanied by necrosis of young leaves or crown which was sometimes lethal, followed infection of UC-1 or EMC plants carrying latent-A virus.

Curly-dwarf Mottle. The symptoms induced in Alpine by the severe forms of curly-dwarf are readily distinguished from those caused by typical mottle virus, but the mildest recognized isolate graded into the intermediate group of typical mottle forms. The symptoms of curly-dwarf differed from those of mottle in that the first symptom of infection was an irregular yellowing of tissues associated with the larger veins of the youngest leaf (Figs. 7, 8, and 9 , left) rather than the characteristic clearing of the net and larger veins on plants infected with mottle. During the chronic stage of curlydwarf infection, the symptoms differed from those of type mottle in that the chlorotic areas were a brighter yellow and occurred as pin-point to large irregularly scattered spots or blotches more obviously associated with veins; the leaves were tougher, more rugose, more obviously blistered, more often and more extremely distorted and misshapen with leaflets of unequal sizes (Fig. 7, center and right; figs. 8 and 9 , right; plate 1 ) ; the petioles were more severely twisted and curled and their lengths on a single plant more variable (Fig. 2, left) ; and in severely diseased plants chlorotic spotting was more obviously expressed, and abnormal flowers were occasionally produced with green, reduced petals and enlarged leaf-like, backward curled sepals. The most characteristic effect of curly-dwarf in $F$. vesca was crown proliferation, dwarfing, and leaf distortion.

The symptoms of some curly-dwarf isolates closely resembled those caused by the combination of mottle with latent-A virus. When those isolates were combined with latent-A virus in $F$. vesca and Royal Sovereign more severe symptoms resulted: the initial severe burning and necrosis of young leaves during the shock stage of infection of $F$. vesca duplicated the symptoms ascribed to the "X" and leaf burn viruses; mild chlorotic and necrotic spots were produced on Royal Sovereign whereas typical mottle isolates caused no, or only transient symptoms in this variety.

Rusty-leaf Mottle. The symptoms of rusty-leaf mottle in Alpine were seldom conspicuous and at times difficult to discern. There was a faint clearing of the veins and a slightly unnatural manner of expansion of the first leaf to show symptoms, sometimes followed by a weakly expressed chlorotic mottle. The most striking, although temporary, symptoms later developed on matured leaves which gradually developed a rusty, yellow or reddish coloration interveinally and especially near the leaf margin at first. Scalding and necrosis of the entire leaf often followed in successive stages beginning at the margins and progressing inward. Simultaneously, the young leaves developed a faint interveinal chlorosis and appeared slightly cupped. Later the plants nearly recovered and appeared almost normal but usually 
the older leaves showed some degree of rusty coloration and necrosis. The plants were only slightly stunted. During the first stage of infection symptoms resembled those of a faint mottle infection and then became similar to those of mild yellow-edge, and finally again similar to those of faint mottle.

In UC-1 plants carrying latent-A virus, infections with rusty-leaf virus caused a conspicuous shock effect. The young leaves developed chlorotic margins which were constricted apically (Fig. 10) and became somewhat cupped and epinastic. They lacked vein clearing or mottle. During chronic stages of the double infection the younger leaves developed a faint mottle while the older leaves tended to become prematurely colored. The lack of necrosis, vein clearing and mottle during the shock stage of the double infection clearly distinguished rusty-leaf from typical mottle virus.

\section{Isolates}

The following isolates of strawberry mottle virus were studied more intensively than others.

Mottle. Isolate 1 (Fig. 2, right) was recovered from an EMC source plant infected with Prentice's type strawberry mottle virus. Segregates of the isolate were expressed on Alpine in the faint, mild, and intermediate symptom groups of mottle. The same virus and range of segregates were isolated on Alpine at Berkeley from a plant of the M35 clone of Royal Sovereign.

Isolate 2 (Fig. 1B) was obtained in California from a Shasta variety field plant; a single variant in the mild symptom group.

Isolate 3 (Fig. 1C) was obtained at Berkeley from a Twentieth Century variety plant; two segregates in the mild and intermediate symptom groups.

Isolate 4 (Fig. 1D) was obtained at Berkeley from a field plant of unknown variety; five segregates in the faint, mild, intermediate, and severe symptom groups of mottle.

At East Malling, eight other isolates were used, each of which appeared to differ at least slightly from any other.

Curly-dwarf Mottle. Isolate 1 (Fig. 7) was obtained from an Auchincruive Climax plant at Berkeley. Segregates were obtained which were of a uniform symptom pattern but which differed in severity and were the least homogeneous of the curly-dwarf mottle isolates. The symptoms were characterized by an irregular chlorotic pattern often appearing as spots on some leaves and absent from others, and by relatively extreme but variable leaf distortion. Undoubtedly the same virus was recovered at East Malling.

Isolate 2 (Plate 1 ) has often been recovered from various $F$. chiloensis clones growing along the coast of Central California. This isolate caused a typical mosaic type of symptom pattern with the chlorotic areas bright yellow.

Isolate 3 (Fig. 8) was recovered from a clone of $F$. vesca californica growing near Stinson Beach in Northern California. It caused symptoms similar to but milder than isolate 2 .

Isolate 4 (Fig. 9) was the mildest of the curly-dwarf isolates. The early symptoms are the yellow vein symptoms of curly-dwarf but the chronic symptoms were difficult to distinguish from those of some forms of typical 
TABLE 1

OBSERVED INCUBATION PERIODS OF FIVE STRAWBERRY VIRUSES

\begin{tabular}{|c|c|c|c|c|c|c|c|c|c|c|c|c|c|}
\hline \multirow{2}{*}{ Virus } & \multirow{2}{*}{$\begin{array}{l}\text { Isolate and } \\
\text { locality* }\end{array}$} & \multirow{2}{*}{$\begin{array}{c}\text { Number } \\
\text { of } \\
\text { periods }\end{array}$} & \multicolumn{11}{|c|}{ Length of incubation } \\
\hline & & & 3 & 4 & 5 & 6 & 7 & 8 & 9 & 10 & 11 & 12 & 13 \\
\hline & & & & & & & & & & & & Nun & ber \\
\hline \multirow{8}{*}{$\begin{array}{l}\text { Mottle } \\
\quad \text { typical form } \ldots \ldots \ldots \ldots\end{array}$} & & & & & & & & & & & & & \\
\hline & 1, EM. & 28 & . & . & . & $\ldots$ & . & 2 & 8 & 10 & 1 & 1 & 2 \\
\hline & $2, \mathrm{EM} \ldots$ & 72 & . & . & . & . & 6 & 18 & 10 & 9 & 3 & 9 & 4 \\
\hline & All $\dagger$, EM. & 165 & . & 1 & 0 & 2 & 15 & 13 & 17 & 25 & 18 & 12 & 22 \\
\hline & $1, B \ldots \ldots$ & 291 & . & . & 2 & 23 & 33 & 54 & 49 & 65 & 34 & 14 & 1 \\
\hline & $2, B \ldots \ldots \ldots \ldots \ldots$ & 152 & . & . & 1 & 9 & 10 & 31 & 38 & 23 & 24 & 3 & 8 \\
\hline & $3, B \ldots \ldots \ldots \ldots \ldots \ldots \ldots$ & 162 & . & 1 & 10 & 17 & 20 & 38 & 37 & 12 & 15 & 10 & 0 \\
\hline & $4, B \ldots \ldots \ldots \ldots \ldots \ldots \ldots$ & 129 & $\cdots$ & . & . & 8 & 12 & 19 & 24 & 25 & 19 & 10 & 5 \\
\hline \multirow[t]{5}{*}{ curly-dwarf form ....... } & $\mathrm{All}_{+}^{+}, \mathrm{EM}$ & 50 & $\ldots$ & . & 2 & 5 & 13 & 5 & 6 & 1 & 11 & 0 & 5 \\
\hline & $1, B \ldots \ldots \ldots \ldots$ & 21 & . & . & 1 & 2 & 7 & 8 & 2 & 1 & . & . & . \\
\hline & $2, B \ldots \ldots \ldots \ldots \ldots \ldots \ldots$ & 107 & 2 & 7 & 10 & 31. & 25 & 20 & 8 & 2 & 2 & . & . \\
\hline & $3, B \ldots \ldots \ldots \ldots \ldots \ldots$ & 92 & . & . & . & 3 & 5 & 20 & 17 & 10 & 10 & 12 & 8 \\
\hline & $4, B \ldots \ldots \ldots \ldots \ldots \ldots \ldots$ & 50 & . & $\cdots$ & $\cdots$ & 4 & 7 & 13 & 9 & 9 & 2 & 5 & 1 \\
\hline rusty-leaf form. . . . . . . . & EM $\ldots \ldots \ldots \ldots \ldots \ldots$ & 13 & . & . & . & . & . & . & . & . & 1 & 0 & 0 \\
\hline Leaf-curl & EM $\$ \ldots \ldots \ldots \ldots \ldots \ldots \ldots$ & 10 & . & . & . & . & . & . & . & . & . & .. & . \\
\hline Vein banding & 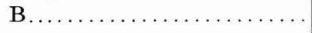 & 131 & . & . & . & . & . & . & . & . & .. & . & .. \\
\hline
\end{tabular}

* EM = East Malling; $\mathrm{B}=$ Berkeley

$\dagger$ Isolate 1 , and nine others.

Infections from three sources containing both curly-dwarf and typical mottle.

UC-1 test plants.

mottle. It was obtained from a clone of $F$. vesca californica growing in the hills near San Francisco.

Rusty-leaf Mottle. A single isolate was obtained at East Malling from an EMC plant as already described.

\section{Incubation Period}

At East Malling, the range of incubation periods of isolates of the typical form of mottle virus was 4 to 21 days with modes of 8 and 10 days (Table 1). At Berkeley the range was 4 to 18 days with modes of 8, 9, and 10 days. The patterns of incubation periods were similar for all isolates at Berkeley and East Malling.

The range of incubation periods of the curly-dwarf mottle virus isolates was determined for the transmissions from the four curly-dwarf infected EMC source plants at East Malling (three of which were also a source of mottle virus) and for the four isolates at Berkeley (Table 1). At East Malling the range was from 5 to 15 days with a mode of 7 days and a nearly equal number of periods of 11 days. This might have been due to the transmission of two viruses with the seventh-day peak having been caused by curly-dwarf isolate 1 (similar to the results at Berkeley) and the eleventh-day peak due to mottle virus. At Berkeley the periods ranged from 3 to 18 days with modes of 6 or 8 days for the individual isolates. In general, the incubation periods of curly dwarf were shorter and more uniform than those of mottle virus although isolate 3 was similar in both respects. 
IN ALPINE TEST PLANTS AT EAST MALLING AND BERKELEY

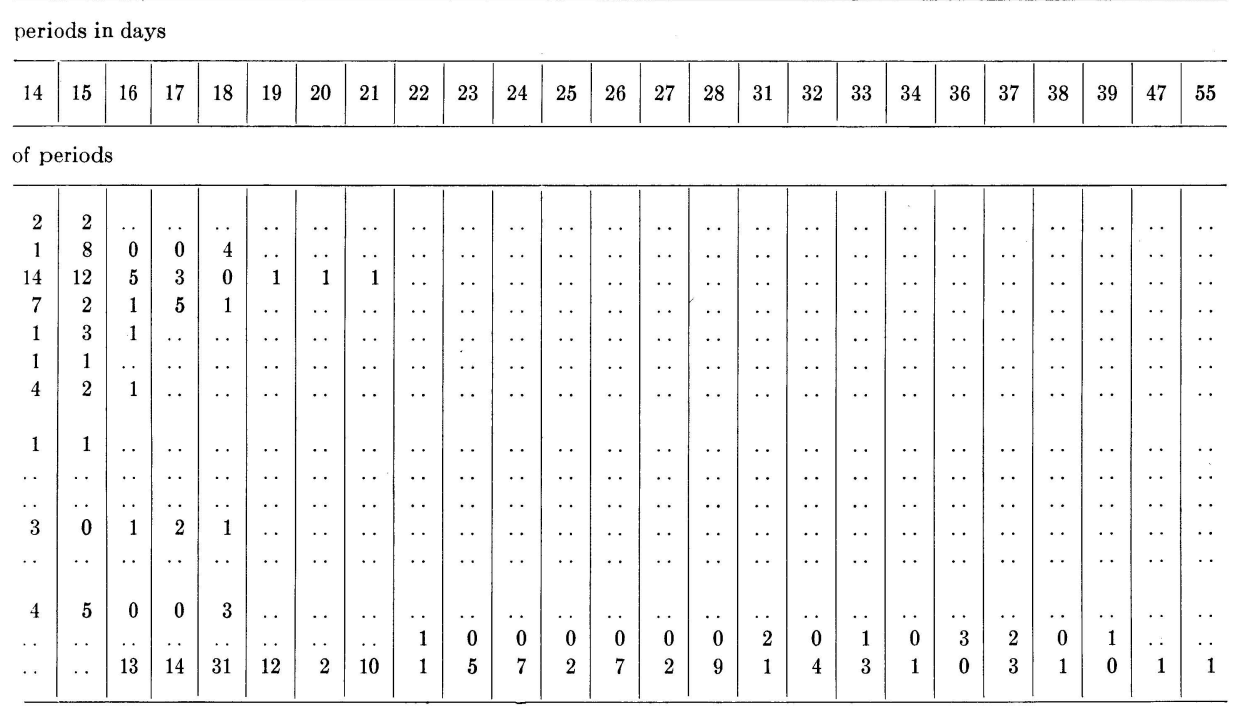

The incubation period of the rusty-leaf mottle virus in 13 plants ranged from 11 to 18 days with a mode of 15 days (Table 1 ).

\section{Transmission of Virus}

Acquisition Threshold Period. The acquisition threshold periods of the four isolates of typical mottle virus were nearly identical in tests at Berkeley. Isolates 1,2 , and 3 were acquired by $P$. t. jacobi in a 50 -minute period, and isolate 4 in a 60 -minute period (Table 2). The shortest acquisition period of the isolates studied at East Malling was 60 minutes.

Data secured at Berkeley with four isolates of curly-dwarf mottle virus showed that virus may be acquired in about 40 minutes (isolates 3 and 4) or slightly longer (isolates 1 and 2) (Table 2). In tests of a different design and not shown in Table 2 a minimum acquisition period of 60 minutes was obtained at East Malling.

No tests were carried out with the rusty-leaf mottle isolate to determine a threshold period.

Retention. The periods of virus retention in P. fragaefolii at East Malling and P. t. jacobi at Berkeley are given in Table 3. It is evident from the table that the maximum period of retention, more than five but not more than six hours, was the same for the isolates of the typical form of mottle at both localities.

At Berkeley the last infections with the curly-dwarf mottle isolates were obtained on either the third or fourth plant of a series so that the indicated maximum period of retention was more than three but not more than four hours. A similar period of retention was indicated by tests at East Malling not included in the table. 
The rusty leaf mottle isolate was transmitted only during the first hour.

Transmission During Short Feeding Periods. At East Malling, a 20hour acquisition feeding period and EMC test plants were used to test transmission of mottle isolate 1 when single $P$. fragaefolii were transferred serially to successive test plants on which they fed for $5,10,10,30,120$, and 120 minutes. Seven aphids transmitted virus to $0,6,5,4,1$, and 0 plants during the sequence respectively.

In a second test in which a 90-minute acquisition feeding period, Alpine test plants, three aphids per plant, and a serial test feeding sequence of 5,10 , and 180 minutes were used, three lots of aphids infected 2, 2, and 1 plants with mottle virus isolate 1 while four other lots infected 0,3 , and 4 plants in the sequence respectively with curly-dwarf mottle.

Transmission by Nymphs vs. Adults. After much of the comparative work had been completed at East Malling a review of the results stimulated a comparison of the transmission by nymphs versus adults of $P$. fragaefolii using the mottle isolate 2 from Berkeley and the standard retention test for the comparison. The nymphs were 24 hours old or less at the start of the 22-hour acquisition feeding period during which both the nymphs and the adults were fed simultaneously on the same leaf of the virus source plant.

Two tests were completed using in the first, 10 lots, and in the second, 20 lots of nymphs and the same number of adults, composed of three aphids per lot. The number of plants infected by the 30 lots during the two tests were, at each successive hourly interval for nymphs and adults respectively: first hour, 17 and 12; second, 13 and 2 ; third, 4 and 3 ; fourth, 2 and 1 ; fifth, 0 and 1 ; sixth, 2 and 0 ; and seventh to twenty-fourth, 0 and 0 . Of the 30 lots of nymphs, 24 transmitted virus but only 13 lots of adults transmitted.

These results indicate a superiority of nymphs in acquiring mottle virus in that greater numbers of them became infective. The nymphs were somewhat erratic in transmitting virus; 7 of the 24 infective lots as compared to 1 of the 13 lots of infective adults, failed to infect the first test plant fed upon; and 1 lot of nymphs infected only the fourth and sixth plants.

\section{Vectors}

The strawberry aphid $P$. fragaefolii has been used at both East Malling and Berkeley, and the species $P$. thomasi and $P$. $t$. jacobi at Berkeley as vectors of mottle virus. Posnette (1952) reported transmission of mottle virus by the aphids Myzus ascalonicus Doncaster and Acyrthosiphon malvae ssp. rogersii Theob.; it is now known that they also transmitted the rustyleaf form of mottle virus. Frazier (1951) recorded that five species of aphids other than strawberry aphids could transmit undetermined strawberry viruses. The viruses can now be identified as the mottle and vein banding viruses and the aphid species which transmitted mottle virus, the number of plants infected and the number of plants tested with each species were, respectively: Amphorophora rubi (Kalt.), 3 of 54; Myzaphis rosarum (Walk.), 11 of 20 ; Macrosiphum pelargonii (Kalt.), 6 of 61 ; Myzus ornatus (Laing), 36 of 144; and Myzus porosus Sanderson, 8 of 20. Transmission by $M$. ornatus has also been obtained at East Malling (Posnette, unpub.).

In three more recent tests of mottle virus transmission at Berkeley, the efficiency of $M$. ornatus was rather erratic. Using acquisition and test feed- 
ing periods of one day each and 10 aphids per test plant, 2 of 33 test plants became infected in test 1 in which 6 virus source plants were used; 4 of 44 plants in test 2 with 5 source plants; and in test 3 , in which 18 source plants were used, 57 of 177 plants became infected. The purpose of these tests was to determine whether $M$. ornatus might transmit different isolates of mottle with varying degrees of efficiency, but this was not detected with the range of isolates used.

In addition to the above species, Aphis gossypii Glover, demonstrated its ability to transmit strawberry mottle virus at Berkeley, confirming the findings of Duffus (1956) in Wisconsin. In seven separate tests in which the acquisition and test feeding periods were of one-day duration, and 1 , 5 , or 10 aphids were used per test plant, 66 of 200 test plants became infected. In other tests in which aphids from diseased field plants were transferred directly to test plants, 8 of 48 test plants developed mottle symptoms. This demonstrated the natural infectivity of the aphid under field conditions.

A. gossypii, like $M$. ornatus, appeared to be an erratic vector of relatively low efficiency. Both species often become abundant on field plants in California and could well be of some importance in the field spread of mottle virus. In England, M. ornatus, $M$. ascalonicus, and $A$. malvae ssp. rogersii may similarly be of importance when populations are sufficiently large to outweigh their inefficiency as vectors.

\section{STRAWBERRY LEAF-CURL VIRUSES}

Leaf-curl virus with strawberry latent-A virus forms a complex that was described by Prentice (1952) as strawberry leaf-curl or virus 5. He transmitted the virus with strawberry aphids after an acquisition feeding period of one hour and found that the virus persisted for about one hour in the vector and had an incubation period in the plant of about five weeks. The virus was originally isolated by aphids from a plant of the North American variety Fairfax and presumably the virus should occur in eastern United States or Canada. The virus is not known to occur in the field in Great Britain. Two other related viruses are known: vein banding virus (Frazier, 1955) and yellow vein banding virus to be described. There are apparent differences in the incubation periods, the acquisition threshold periods, and the persistence in the vector of the three viruses but the symptoms of all three are much alike and a strain relationship is considered to be probable.

\section{Leaf-curl Virus}

Symptoms. In EMC, UC-1, and latent-A carrying UC-1 plants, leaf-curl virus induced less severe symptoms in both the early and chronic stages of infection than vein banding virus. Attempts to infect Alpine were not successful.

The first symptoms in UC-1 plants were a discontinuous, diffuse yellowing of tissue along main veins of the youngest expanding leaf, usually accompanied by slightly retarded leaf expansion and weak down curling of the midribs of affected leaflets. Leaves formed later usually had at least a trace of vein banding, but series of symptomless leaves were sometimes produced (Fig. 11). There was a tendency for premature yellowing of older 
leaves, especially those having more pronounced banding; they were also slightly curled backward.

The symptoms of the leaf-curl disease complex (latent-A virus plus leafcurl virus) in EMC and UC-1 plants were those given by Prentice (1952) for leaf-curl. Epinasty of the petiole accompanied the first symptoms on the youngest leaf, leaflets were backwardly recurved with a diffuse chlorosis along portions of the main veins. These symptoms usually persisted in some degree during the chronic stage of the disease (Fig. 12) when the plants were appreciably stunted, the older leaves prematurely yellowed or reddened and necrotic. A rusty or purple discoloration usually developed along veins of matured leaves, often becoming necrotic. This symptom has been noted only when latent virus accompanied leaf-curl virus or vein banding virus, but similar symptoms may result from causes presumably other than virus.

Incubation Period. Based on records of 10 infections the incubation period of the virus symptoms ranged from 22 to 39 days with a mode of 36 days (Table 1).

Transmission. Two Royal Sovereign plants derived by vegetative propagation from plants infected by aphids in 1948 were used as sources of virus. Several attempts failed to recover virus from them by strawberry aphids. Virus was transmitted from both source plants by grafting to indicator plants from which aphids were then able to acquire the virus. This experience parallels that of Prentice (1952) who found that plants which had been infected over long periods were poor sources of virus.

One standard test of virus retention was carried out using an aphid infected UC-1 source plant and 10 lots of aphids. Six of the 10 lots infected the first serial test plant fed upon during the first hour, while one lot also infected the plant fed upon during the second hour, as shown in Table 3. These few data agree with and merely augment those already given by Prentice (1952).

In a single trial using lots of about 30 Amphorophora rubi, two of three lots transmitted leaf-curl virus. This represents a point of similarity with vein banding virus which is also transmitted by $A$. rubi.

\section{Vein Banding Virus}

An account of the vein banding virus from Marshall has already been published (Frazier, 1955b) but some of the published data concerning the incubation period, acquisition threshold period, and virus retention in the vector are included here in a different form in Tables 1,2 , and 3, respectively, to afford a direct statistical comparison with data on other viruses.

Frazier (loc. cit.) gave the transmission records of six colonies of $P$. fragaefolii in Table 2. Since publication of the data, it has been determined that both of the pale aphid colonies which failed to transmit vein banding virus were the species $P$. thomasi, the two pale colonies which transmitted efficiently were both $P$. fragaefolii, while both of the dark aphid colonies which also transmitted the virus efficiently were the species $P$. thomasi ssp. $j a c o b i$. The evidence suggested that inability to transmit vein banding virus may perhaps prove to be a characteristic of $P$. thomasi. It was also reported that $A$. gossypii was probably not a vector of vein banding virus on the 
basis of 23 plants tested; this has been further supported by a more recent test in which no infections resulted in 14 plants tested with 10 aphids each.

\section{Yellow Vein Banding Virus}

The yellow vein banding virus has been isolated both by aphids and by grafting from symptomless plants of $F$. chiloensis growing along the sea coast near Montara, California. The symptoms were more like those of vein banding virus than leaf-curl virus.

Symptoms. The symptoms characteristic of yellow vein banding are known only in Alpine and UC-1 indicator plants. They were most easily distinguished from those caused by vein banding virus during the early stage of infection (Fig. 13) but with greater difficulty during the chronic stage. The first symptom of yellow vein banding infection in Alpine plants usually was a fine clearing of the veins (Fig. 14A, left); sometimes lengths of main veins were narrowly banded but not as conspicuously as was the case with vein banding virus infections (Fig. 14B, right). A vein banding pattern was not usually prominent on the first several leaves to expand after infection, but developed gradually.

Compared with the chronic symptoms of the vein banding virus, the vein banded areas were narrower with more sharply defined margins and of a brighter yellow; petioles tended to be shorter without corresponding reduction in leaf size; leaflets and petioles were often slightly epinastic and old leaves developed a more pronounced premature yellowing and curling. The symptoms of both viruses fluctuated in intensity during the chronic stage, especially in response to fertilizer; as the differences between them were not great, diagnosis may often be rather uncertain.

Incubation Period. In Alpine test plants infected by aphids the incubation period in 15 plants ranged from 18 to 35 days with a mode of 28 days; this was 10 days longer than that for the vein banding virus at Berkeley and 8 days shorter than for the leaf-curl virus at East Malling.

\section{STRAWBERRY MILD YELLOW-EDGE VIRUS}

The name "mild yellow-edge" applies to the virus which, in combination with other strawberry viruses, causes the disease described as yellows (Plakidas, 1926), Xanthosis (Plakidas, 1927), yellow-edge (Harris, 1933), and which was termed virus 2 and strawberry mild yellow-edge virus by Prentice (1948).

\section{Symptoms}

Prentice (1948) noted three symptom patterns and suggested that his virus 2 might be a complex capable of further resolution. The three isolates of Prentice, others isolated more recently at East Malling, and a form of virus 2 common in California Shasta plants, were available for comparative study at East Malling. The East Malling isolates were all in EMC or Royal Sovereign plants which would presumably have been infected also with latent-A virus.

The symptoms of the different isolates in the EMC plants were basically similar, although they varied in the degree of chlorotic spotting, cupping, marginal chlorosis of younger leaves, premature yellowing, interveinal 
necrotic spotting or marginal burning of older leaves, and in the vigor of the affected plant. There were three distinct symptom patterns: (1) Prentice's virus 2 type, the most severe form characterized by vein clearing, chlorotic flecks on veinlets, mild chlorosis with cupping of young leaves, and development of necrotic spotting accompanied or preceded by yellow or reddish discoloration of older leaves followed by scalding or premature death of the leaves. EMC plants may be severely weakened or killed; (2) Described by Prentice as a mild form of virus 2 and characterized by chlorotic spotting with less cupping of young leaves and interveinal necrotic spotting on older leaves; and (3) Described by Prentice as virus 2 from Huxley's Giant and characterized by a nonmottled chlorotic stunt, with mild cupping and chlorosis of younger leaves and marginal reddening and burning of older leaves.

Attempts were made to separate the mild yellow-edge viruses from the latent-A virus by transmitting them by aphids to Alpine or UC-1 plants. Seven EMC plants infected with different East Malling isolates of virus 2 and one plant each of the varieties Shasta and Lassen from California were used as virus sources. Aphids were given two- and four-day acquisition feeding periods and then transferred serially to fresh Alpine test plants daily until the last aphid died. In the two-day acquisition group a single lot of 10 aphids was transferred from each of the nine source plants and the maximum survival was 14 days. In the four-day group the numbers of aphids transferred to the first test plant from each virus source ranged from 4 to 10 and the maximum survival was 12 days. Only three infections resulted in 206 test plants and all three originated from a single source plant showing the severe symptom pattern of Prentice's virus 2 type. This virus, in previous years, had seemed more readily transmitted by aphids than other virus isolates.

The aphids of the two-day acquisition group infected the test plants fed upon during the fourth and sixth days while aphids from the four-day group infected the plant fed upon during the seventh day. The symptoms developed about five weeks after inoculation. Virus was transmitted by graft from one of the Alpine plants to two UC-1 plants. Although unions were not established in either graft, symptoms similar to those in the Alpine resulted in one of the UC-1 plants while in the second plant dissimilar symptoms appeared.

Infection in the Alpine and first UC-1 plant was first noticeable by the development of vein clearing and faint mottling on the youngest leaf. The plant gradually became weaker, the young leaves mildly chlorotic, reduced, with or without faint vein clearing or mottling and without cupping. Commencing shortly after initial symptoms of infection the older leaves colored prematurely in a chlorotic to rusty mottled pattern in which necrotic areas developed which spread to kill the leaf. Infected plants became very weak or died. The effect of the virus on Alpine and UC-1 was more severe than on the EMC source plant.

The symptoms which developed in the second UC-1 plant consisted of a marginal necrosis that appeared on several of the leaves. The symptoms were milder than but of a very similar pattern to those that developed 
on a UC-1 plant which was grafted to an EMC plant infected with Prentice's mild yellow-edge virus from Huxley's Giant (pattern 3, above). The UC-1 plant developed a nonmottled chlorotic stunt with reddening and burning of the margins of older leaves, suggesting that the aphid-infected Alpine plant may have been carrying two viruses, one of which was similar to the virus from Huxley's Giant.

Additional attempts were made to transmit virus from Royal Sovereign and EMC source plants with long-standing infection and from several UC-1 and Alpine plants recently infected by aphids. Using five different source plants on which colonies of aphids were placed, lots of five aphids were removed daily for five days, each lot fed 24 hours on a UC-1 test plant and transferred daily thereafter to successive UC-1 plants until all aphids in each lot were dead (a maximum of eight days). Twenty-eight lots of aphids fed upon 143 test plants but only one developed symptoms; this was infected during the third day of test feeding by aphids having had a threeday acquisition feeding period. The source plant was that (with the severe symptoms) from which virus was transmitted during the earlier aphid tests described above. However, the symptoms that developed were not the same as those on other plants; they were more like those of Prentice's mild form of virus 2 and perhaps represent the second of two viruses infecting the EMC source plant.

The first symptom consisted of a rusty-colored line pattern on an older leaflet followed by gradual development of nearly typical mild yellow-edge symptoms (pattern 1) but less severe and included mild vein clearing, rather pronounced chlorotic spotting of younger leaves, discoloration and spotting of older leaves. After several months of well-marked symptoms the plant recovered and became nearly symptomless. Attempts to retransmit the virus by aphids were not successful.

The symptoms of the severe form of mild yellow-edge virus, which was transmitted by aphids to the three Alpine plants and then graft transmitted to a UC-1 plant, appeared to be similar to or identical with the symptoms commonly produced on the same hosts in Berkeley (Plates 2 and 3 ) as a result of yellows virus infections. In California the virus causing such symptoms is of common occurrence. The variety Shasta appears to be universally infected, and since Shasta plants were available at East Malling it was possible to compare directly the symptoms of the California and English viruses by grafting to indicator plants. UC-1 plants were used for this purpose and symptoms of the California virus and the severe East Malling aphid transmitted virus appeared to be indistinguishable.

\section{Transmission}

In our work at East Malling the nearly complete failure of aphids to transmit Prentice's three symptom types or the California virus from Shasta even when Shasta was used as a breeding host for long periods of time added little to our knowledge and provided no basis for evaluating relationships.

Prentice (1948) demonstrated that virus 2 could be acquired by strawberry aphids during a 24-hour infection feeding period and then be transmitted to the first test plant during a 24-hour test feeding period and that the virus could persist in the aphid longer than 12 days. In some of his 
experiments two of his symptom types appeared on his indicator plants but he did not present data for either type separately. He (1952) concluded that his data gave no evidence of a latent period in the vector, or if one did exist it did not exceed 24 hours based on the assumption of a 24 -hour acquisition threshold period.

Subsequent results obtained by Posnette and Cropley (Table 4) suggested that mild yellow-edge virus usually has a latent period in the aphid, but the period varied with different lots of aphids in each test. An alternative interpretation was indicated by one test (exp. 7) that aphids transmit erratically so that the chance of infection increases with feeding time. Two tests (exps. 2 and 7 ) demonstrated that the virus can be transmitted within six hours following the end of an acquisition feeding period.

A number of tests to gain information on the vector-virus relationships of the mild yellow-edge virus from Shasta, Marshall, and other sources have been carried out at Berkeley, but transmission was nil in nearly all tests. In only one test, to determine an acquisition threshold period, was transmission satisfactory; the source was an Alpine plant infected with a virus originally from a Lassen variety plant and transmitted by aphids through several subtransfers. $P$. $t$. jacobi aphids were allowed acquisition feeding periods of 1,8 , or 24 hours, $2,3,4,5,6$, and 7 days. At the end of each period two aphids were transferred to each of 10 Alpine test plants where they fed until the combined acquisition-test feeding periods totaled 14 days. No transmission occurred after the one-hour acquisition feeding period, but $1,3,2,2,3,3,4$, and 3 of 10 test plants became infected following the 8- and 24-hour, 2-, 3-, 4-, 5-, 6-, and 7-day acquisition feeding periods respectively. The acquisition threshold period therefore is eight hours or less at Berkeley.

In the above test, symptoms developed in most test plants in 32 to 39 days but the aphids had fed on the plants from 7 to 14 days so that an incubation period cannot be determined. In several other infections incubation periods of 18 and 19 days have been recorded.

\section{Vectors}

Strawberry mild yellow-edge virus has been transmitted by $P$. fragaefolii at both East Malling and Berkeley, and at Berkeley also by $P$. thomasi and P. $t$. jacobi. Aphids which have failed to transmit mild yellow-edge and the number of plants on which they were tested are: Aphis forbesii Weed, five plants ; A. gossypii, 58 plants ; Amphorophora rubi, 14 plants ; Macrosiphum pelargonii, 10 plants; Myzus ornatus, 29 plants; M. ascalonicus, 20 plants; and Acyrthosiphon malvae rogersii, 15 plants.

\section{Symptoms}

\section{STRAWBERRY CRINKLE VIRUSES}

A number of intergrading virus forms which cause similar characteristic symptoms in complex infections with other viruses appear to constitute a homogeneous group; the same range of forms is known in both England and on the Pacific Coast and undoubtedly some of the causal viruses are the same. Little is known of their vector relationships. Symptoms are of a similar 
pattern but vary in the severity of expression. The symptom characters on Alpine, UC-1, and EMC plants include:

1. Chlorotic spotting. Initially translucent, later opaque yellow, often becoming reddish or necrotic; pin-point to large, irregular in outline, scarce to abundant, irregularly distributed, and associated with veins.

2. Vein chlorosis. Not usually conspicuous. Small veins may become narrowly cleared along a short length or in a small network usually in association with a chlorotic spot.

3. Crinkling. The crippling effect on expanding leaves of chlorotic and necrotic spots causes uneven expansion with consequent abnormalities of crinkling, outward angular bending of leaflet sectors, unequal size of leaflets, and leaflet necrosis.

4. Lesions. Greenish to reddish discolored or necrotic, swollen or sunken spots, areas, or rings on stolon, petiole, peduncle, or main veins, often causing angular crooking at point of lesion.

5. Chlorotic sectoring. Interveinal tissues bordering a main vein become dully chlorotic from some point in the vein to the leaflet margin; the area often widens apically to form a wedge-shaped sector.

6. Stunting. Petioles may be greatly shortened and leaf size reduced.

Symptom expression fluctuates with environmental factors and duration of infection.

All of the crinkle virus forms that have been tested interact with mottle virus to produce shock symptoms (Figs. 4 and 17) that may include epinasty, necrosis of young leaflets and stolon tips and, with some isolates, even the death of the plant; chronic symptoms (Figs. 16 and 17) are those of mild crinkle or severe crinkle. They also interact with leaf-curl viruses to produce symptoms of the type already noted for the complex with latent-A virus (Fig. 12).

The viruses composing this group are also alike in that attempts to transmit them experimentally with strawberry aphids have met with little success. The failure is possibly due to the difficulty experienced in keeping test aphids alive long enough to complete the long latent period required for the transmission of crinkle.

The following viruses are thought to be related either as strains of a single crinkle virus or as viruses and strains of the crinkle type. They are discussed in order of increasing virulence.

\section{Strawberry Latent-A Virus}

Frazier (1953) first detected the strawberry latent virus, strain A, in two stocks of the East Malling F. vesca indicator clone. Subsequently, further tests indicated that the virus was probably present in all of the stocks of the clone in use as an indicator plant in North America. What appears to be the same virus has also been detected in a wild clone of $F$. vesca var. californica in the Coast Range Mountains of San Diego County, California, and from normal appearing nursery stock of the variety Marshall. It is not known whether the nursery clones had at some time been indexed to the East Malling clone or whether the infections were natural.

As the name indicates, the virus caused no symptoms in any of a number 
of seedling indicator clones except for a slight loss of vigor. The addition of mottle virus caused definite but relatively mild shock and chronic symptoms. Severe forms of mottle virus alone produced similar and even more severe symptoms than when mild forms of mottle were combined with latent-A. The symptoms of the virus complex, however, characteristically included evidence of opaque yellowish "scar-tissue" spots and a tattered effect at leaflet margins (Fig. 17).

The fact that latent-A virus was a universal contaminant of the East Malling $F$. vesca indicator clone at the East Malling Research Station was inferred from the symptoms that resulted on mottle-infected plants, and proved by graft transmission of the latent-A virus from each of 16 EMC plants to UC-1 or EMS-1 plants which were later infected with mottle virus and then produced mild crinkle symptoms.

Probably the wild parent of the EMC clone was carrying the virus since in the original comparative tests it appeared to be more sensitive and displayed more marked symptoms than other plants and was selected as an indicator for that reason.

Neither at East Malling nor at Berkeley have efforts to transmit the virus with strawberry aphids met with success, but only in relatively few tests have the aphids survived longer than 14 days after commencing the acquisition feeding period.

\section{Strawberry Latent-B Virus}

The B strain of latent virus (Frazier, 1953) was quite similar to latent-A virus. It differed in that its combined effect with mottle (Figs. 16 and 17) or the leaf-curl viruses caused noticeably more severe shock and chronic symptoms; by itself latent-B virus caused slight symptoms in UC-1 plants although it was symptomless in other indicator clones tested. The symptoms in UC-1 consisted of very small yellowish spots, rarely numerous or obvious, often appearing only singly on a leaf (Fig. 18, left). Periodically infected plants may be either symptomless or exhibit easily detected symptoms. Stolon or petiole lesions have been observed rarely and only on plants after infection with mottle virus.

The virus has been transmitted by grafting from several Marshall plants and from wild $F$. vesca var. californica plants from several coastal localities in California. Aphid transmission of latent-B virus has not been achieved in a small number of unsatisfactory tests. It is not known whether this virus occurs in England.

\section{Strawberry Lesion-A Virus}

Strawberry lesion-A virus is the name given to a virus isolated with the dark strawberry aphid, $P$. $t$. jacobi, from a naturally infected $F$. vesca californica plant from the Coast Range Mountains in Santa Clara County, California. The six aphids which were naturally colonizing the infected plant were transferred to three successive healthy UC-1 plants where they fed for one, two, and four days respectively. About 17 days following removal of the aphids all three test plants developed similar primary symptoms which consisted of lesions on petioles and stolons (Plate 4), and a backward, 
angular bending of the midrib of one or more young leaflets (Fig. 19). Only one or two successive leaves developed the backward bending, and lesions were never numerous. Vein clearing or chlorotic spotting has never been observed during any stage of infection.

When mottle or vein banding virus was added to plants infected with lesion-A virus the shock effect was similar to, but more severe than, that on plants infected with the latent-B virus, but chronic symptoms were milder than those of the latent-B complex in that the scar-tissue spotting and marginal tatter-leaf effect were much less obvious.

Intergrafting of plants infected with lesion-A and latent-B resulted in additive symptoms only. The appearance of lesions on the latent-B and chlorotic spotting on the lesion-A plants took place gradually without shock or primary symptoms. This lack of synergism between the two viruses is thought to be an indication of their close relationship.

The few attempts to retransmit lesion-A virus with $P$. $t$. jacobi have not succeeded.

\section{Lesion-B Virus}

A virus resembling lesion-A but causing more severe symptoms was isolated by means of $P$. fragaefolii at East Malling during a test of mottle virus transmission. For this test the progeny of field-collected aphids colonized on Royal Sovereign, Huxley's Giant, and other varieties were used. Virus sources consisted of leaves detached from 10 mottle-infected EMC plants on which the aphids were given an 18-hour acquisition feeding period in Petri dishes. One lot of 6 to 12 aphids from each leaf was then transferred at hourly intervals to four successive Alpine test plants and remained on the last plant for 21 hours. Two lots transmitted mottle virus to the first plant fed upon, while a third lot infected the first and second test plant in its series with lesion-B virus.

The first symptoms appeared on the lesion-B infected plants 16 and 18 days following inoculation. The youngest leaf developed a moderate outward rolling or arching of leaflets accompanied by a faint vein chlorosis and the appearance of lesions on the petiole. Two successive leaves exhibited the leaflet symptoms and thereafter the plants were apparently normal except for the occasional development of lesions on petioles or peduncles. After several months the virus was grafted into UC-1 plants from one of the infected Alpine plants. Lesions and outward arching of leaflets appeared initially as primary symptoms in the UC-1 plants but later a chlorotic vein spotting of the crinkle type (Fig. 20) developed on the UC-1 plants and on daughter plants that had been propagated from them. The spotting was not conspicuous and seemed more evident in pot-bound plants.

The effect of mottle virus on UC-1 plants with lesion-B was more severe than that on UC-1 plants with latent-A virus.

Further transmission of the lesion-B virus with aphids was attempted from the original EMC source plant, the aphid-infected Alpine and graftinfected UC-1 plants. No transmissions resulted although the different lots of aphids completed combined acquisition-test feeding periods of from 12 to 20 days on Alpine, UC-1 or seedling $F$. vesca test plants. It seems most 
probable that the aphids must have acquired the virus for the two original transmissions to Alpine from the stock colony plant rather than from the EMC excised leaf on which they spent the acquisition feeding period of 18 hours; otherwise the indicated vector relationships would be of the order of mottle virus rather than of crinkle.

\section{Vein Chlorosis Virus}

Vein chlorosis virus was characterized by Prentice (1952) as a possibly persistent type virus that caused vein chlorosis (or narrow yellow vein banding) and necrosis on Royal Sovereign and slight chlorotic spotting on EMC. The symptoms were so slight and evanescent that he was unable to conclude from his experiments whether the virus was transmissible by the strawberry aphid.

Evidence indicating the ability of $P$. fragaefolii to transmit vein chlorosis virus was obtained by Posnette and Cropley (unpublished) in a test in which, after a four-day acquisition feeding period on either a Royal Sovereign or Huxley's Giant virus source plant, 15 aphids per plant were transferred serially to three successive sets of 10 Royal Sovereign test plants for test feeding periods of four hours, six days and six days. No infection occurred in the first two sets of plants but three of the 10 plants of the third set became infected. The results suggested a type of vector relationship similar to that of crinkle.

For the present study at East Malling six EMC plants were selected for testing as virus sources. One plant was infected with Prentice's type vein chlorosis virus; the other five were infected with other isolates thought to be of the same virus. Symptoms in the six plants varied from none (Prentice's type plant) to mild but definite chlorotic spotting of the crinkle type. Symptoms were not constant but varied in intensity; occasionally short lengths or a small network of subsidiary veins appeared yellowed or narrowly banded (Fig. 21) and a few lesions were observed to develop on most of the plants.

One transmission test of vein chlorosis virus was carried out with strawberry aphids. Populations of very young nymphs were given a two-day acquisition feeding period on each of the six EMC source plants. The surviving population on each plant was divided into three equal lots which varied from 13 to 20 aphids and transferred to successive test plants on the first, second, fifth, eighth, tenth, twelfth, fourteenth, sixteenth, and nineteenth day of the test feeding period. All aphids were dead on the twentyfirst day. One of the three lots from each source plant was fed only on seedling F. vesca, Huxley's Giant, or Royal Sovereign, or UC-1 test plants during the first 14 days but a shortage of plants made it necessary to substitute EMC plants during some of the later transfer periods.

Three definite cases of virus transmission resulted, all from a single source plant. One plant had been inoculated during the 16- to 18-day interval by five aphids; the other two had been inoculated by single aphids during the 19- to 20-day interval. All three infected test plants were EMC plants already carrying latent-A virus. Symptoms consisted of lesions and chlorotic spotting which were first noticed about three months after inoculation. No primary 
or shock symptoms were observed. The symptoms were very similar to those that developed on UC-1 plants infected with lesion-B virus and it is possible that lesion-B was the virus actually transmitted as the source plant may have been carrying it in addition to vein chlorosis virus. The apparent absence of a short incubation period of about 17 days such as was the case with both strains of lesion virus might have been due to an effect of the latent-A virus in suppressing the primary symptoms of the related lesion virus.

Since a virus was not successfully isolated on virus-free indicator plants from any of the six vein chlorosis source plants it is yet to be determined precisely whether vein chlorosis virus causes symptoms in the absence of latent-A virus. However, because of the symptoms expressed on the EMC source plants, on UC-1 plants grafted to them, on mottle-inoculated daughter plants of the source plants, and because of the type of aphid transmission of the virus obtained by Posnette and Cropley, it appears probable that vein chlorosis virus approximates either latent-B, or more likely lesion-B virus; it is included with them here as a crinkle virus or strain although further work might indicate a different relationship.

\section{Strawberry Crinkle Virus}

Prentice (1949) described the symptoms of crinkle virus produced on EMC and Royal Sovereign with details of transmission of the virus by strawberry aphids and of its persistence in the vector for a number of days, and determined the incubation period of the disease in the plant to be between four and eight weeks. Later, with Woollcombe (1951) he demonstrated that the virus could be acquired by the vector during a 24-hour feeding period but that a long latent period of about 12 to 16 days must elapse before the aphids could transmit the virus.

For study at East Malling, 10 EMC virus source plants were chosen exhibiting a graded series of crinkle symptoms. The symptom patterns differed more in the intensity of expression than in the kind of symptoms; all included lesions, chlorotic spotting, vein chlorosis and necrosis, and crinkling; most also exhibited chlorotic sectoring of leaflets and these showed the greatest fluctuation in petiole length and downward angling or arching of leaflets. The plant infected with Prentice's type crinkle virus showed one of the milder patterns, not much more severe than those included among: the vein chlorosis virus source plants.

Several tests were completed in attempts to transmit virus from all 10 source plants to virus-free test plants by means of the strawberry aphid but transmission was not detected in any test.

At Berkeley a similar series of crinkle symptoms has been produced on indicator plants by graft and aphid transmission (Fig. 18). The virus sources have included commercial varieties from Pacific Coast states, $F$. $v$. californica and $F$. chiloensis. Crinkle virus has been transmitted only by naturally infective aphids found on diseased plants in the field and not by aphids from stock colonies experimentally. One of several groups of naturally infective aphids infected test plants on five successive days.

The primary svmptom of angular backward bending or crooking of leaf- 
lets accompanied by petiole lesions and usually also by chlorotic vein flecking (Fig. 22) developed on all plants infected by aphids. The symptoms were more pronounced than those of the lesion viruses and there was no recovery. The incubation periods for 21 plants ranged from 6 to 26 days with a mode of 10 days. This is very close to the 12- to 15-day incubation period as first reported for crinkle by Zeller (1933). When indicator plants carrying latent or lesion viruses have been graft-infected with crinkle virus, the crinkle symptoms have developed gradually without any evidence of the primary leaflet crooking characteristic of crinkle infection in virus-free indicator plants. This, again, presumably indicates a relationship between the latent, lesion, and crinkle viruses, and may account for the four- to eight-week incubation period of crinkle virus in latent-A carrying EMC and Royal Sovereign plants observed by Prentice (1949).

\section{ASTER YELLOWS VIRUS}

In California the incidence of aster yellows in strawberry plantings has been very erratic from year to year. The disease is usually rare or of negligible importance, but during some years and especially in the northern area where nurseries are located, the disease has caused much concern.

The symptoms on the Lassen variety and on indicator plants have been previously described and an account given of transmission by leafhopper vectors (Frazier and Thomas, 1953). Since then the disease has been observed on many, and the virus recovered from several, other commercial varieties and seedlings. Symptoms in the field may differ in different varieties, although of a similar basic pattern, and are influenced by environmental conditions. In Lassen the virus caused a severe "yellow-edge" type of symptoms accompanied by phyllody and proliferation of flowers, but in Shasta (Fig. 23) it caused scalding of the leaves, cessation of growth, wilting, and rapid death of the plant; intermediate degrees have been observed on other varieties (Fig. 24). The disease is usually lethal, especially under conditions of high temperature and low humidity. Some plants recover partially and may live for a long period in a weakened state. One Lassen plant was transplanted into the glasshouse and eventually died, but not before an adventitious bud developed just above soil level and became self-rooted. This bud grew into a very vigorous plant which, with its daughter plants, has indexed virus-free for several years.

Considerable difficulty was encountered in attempts to infect strawberry using leafhopper vectors, but recovery of the virus from diseased strawberry plants by leafhoppers was accomplished more readily. Recent attempts to recover aster yellows virus from different diseased strawberry plants using broad-leaved plantain (Plantago major L.) as a test plant with Macrosteles fascifrons (Stål) and celery (Apium graveolens L. var. dulce Pers.) with both Colladonus geminatus (Van Duzee) and C. montanus (Van Duzee) resulted in recovery of the virus from 4 of 15,1 of 5, and 1 of 3 plants by the three leafhopper species respectively, using groups of more than 30 leafhoppers per plant.

$M$. fascifrons was allowed to breed on plantain plants infected by leafhoppers with virus from strawberry. Adults which had developed from eggs 
in the plant were eaged in groups of $30,50,75$, or more than 100 individuals on 34 strawberry plants including Marshall, Lassen, Climax, Royal Sovereign seedlings, and $F$. vesca and on one Duchesnea indica Focke. No infections resulted in any of the strawberries, but the $D$. indica developed symptoms of aster yellows with chlorotic, cupped, dwarfed leaves, twisted petioles, and stunt. There was eventual death without flower development.

In attempts to infect strawberry plants with virus directly from diseased strawberry by means of previously noninfective leafhopper vectors, $M$. fascifrons and $C$. montanus failed to infect four and three plants respectively, but $C$. geminatus infected one of three Lassen test plants.

The symptoms that developed on plantain with virus from different strawberry sources appeared to differ from the symptoms developing on plants infected with virus from stock greenhouse cultures. To test this observation a series of 11 test host plants were propagated and five plants of each were inoculated with aster yellows virus from a strawberry source and five from a greenhouse culture in aster by means of previously noninfective $M$. fascifrons. Of the 11 hosts tested, seven of them including zinnia (Zinnia elegans Jacq.), potato (Solanum tuberosum L.), alfalfa (Medicago sativa L.), pinto bean (Phaseolus vulgaris L. var. humilis Alef.), and Lassen, Marshall, and Alpine strawberry remained healthy. Four hosts, plantain, aster (Callistephus chinensis Nees.), carrot (Daucus carota L. var. sativa DC.), and celery became infected $; 5,4,5$, and 5 plants respectively with the virus from strawberry and $5,3,2$, and 5 plants respectively with virus from the aster stock source.

Differences in symptoms were obvious in all plants according to the virus source. In all four hosts the strawberry virus caused more severe stunting and a more severe chlorosis and dwarfing of leaves (Fig. 25). On plantain a black, tar-like exudate was formed on petioles only of plants infected with virus from strawberry.

To test the possibility of strain cross protection between the viruses from the two sources, 15 plantain plants were infected with virus from the stock culture. When symptoms had developed in all plants, 10 of them were reinoculated with virus from the strawberry source and at the same time five healthy control plants were also inoculated. All the control plants developed the characteristic symptoms of the strawberry virus. Two of the doubly inoculated plants continued to display the same symptoms as the singly infected plants with virus only from the stock culture and may be presumed either to have escaped infection during the second inoculation, or to represent examples of protection ; the other eight doubly infected plants developed symptoms that were intermediate or equal to those of the strawberry isolate. It was concluded that this test indicated a lack of complete cross protection between the two virus isolates.

To see whether other variants of aster yellows occurred and whether the form found in strawberry might occur in other hosts, virus transfers to plantain or aster were made from five naturally infected celery, two filaree (Erodium moschata L'Her.), seven horseweed (Erigeron canadensis L.), three Epilobium paniculatum Nutt., and three Indian tobacco (Nicotiana bigelovii Wats.) plants collected in eight widely separated localities of north- 
ern and central California. The results indicated that several symptom forms of the virus existed in nature. Both the strawberry and greenhouse culture isolates appeared to have been duplicated, and one apparently distinctive form was recovered from two celery plants. It is not known whether the symptom forms represent merely variants of a single strain or different strains of the aster yellows virus.

'The susceptibility of Duchesnea indica and Nicotiana bigelovii is thought to constitute the first record of those plants as hosts of the aster yellows virus. The naturally infected Indian tobacco plants exhibited typical aster yellows symptoms including stunting, general chlorosis of the plant, axillary shoots, yellow venation of leaves, and phyllody of flowers.

\section{GREEN PETAL VIRUS}

The green petal virus (Posnette, 1953b) has not been demonstrated to occur elsewhere than in Great Britain although similar symptoms have been reported from Nova Scotia (Gourley, 1955). Accounts of the symptoms, host range, and vector-relationships of the virus have been given elsewhere (Frazier and Posnette, 1956, 1957). The presently available data do not afford a critical evaluation of its relationship to other leafhopper-transmitted viruses such as aster yellows, stolbur, and cranberry falseblossom. On the basis of symptoms in common hosts such as aster, celery, carrot, $D$. indica, and plantain, green petal seemed clearly distinct from both the eastern and western strains of aster yellows. On other common hosts such as red clover and tomato the symptoms were similar to those of aster yellows and a strain relationship between the viruses cannot be precluded.

\section{RASPBERRY YELLOW DWARF VIRUS}

Raspberry yellow dwarf virus has been shown by Harrison (1958) to cause the strawberry disease called "yellow crinkle" by the East Malling workers. This name is descriptive of the symptoms on several varieties including Cambridge Favourite, Cambridge Vigour, Deutsch Evern and Huxley's Giant. The leaves are crinkled and blotched with yellow areas (Fig. 26), but the disease differs from crinkle in that varieties tolerant of the latter disease are severely affected by yellow crinkle, while Royal Sovereign which is sensitive to the crinkle viruses seems more tolerant of raspberry yellow dwarf virus. This suggests that yellow crinkle is also distinct from strawberry mosaic disease which is severe on Royal Sovereign, but further investigation may reveal a relationship.

Raspberry yellow dwarf virus is soil-borne and also transmissible by sap inoculation from strawberry to a wide host range including Beta vulgaris, Chenopodium amaranticolor, Nicotiana spp., Petunia hybrida and Phaseolus vulgaris (Harrison, loc. cit.). Yellow crinkle disease is widespread in southern England and outbreaks have undoubtedly been attributed in the past to an unusually virulent strain of the crinkle virus.

\section{RASPBERRY RING SPOT VIRUS}

Raspberry ring spot virus (Cadman, 1956) has been transmitted from naturally infected strawberry plants by sap inoculation to Chenopodium ama- 
ranticolor (Lister, 1958). The strawberry plants (vars. Cambridge Vigour, Early Cambridge and Talisman) were stunted with symptoms of the yellow crinkle type. Although raspberry ring spot virus causes symptoms similar to those of raspberry yellow dwarf virus in strawberry, it produced local lesions instead of systemic infection in $C$. amaranticolor and characteristic symptoms in the other species mentioned in the host range of raspberry yellow dwarf virus.

Raspberry ring spot virus is soil-borne (like raspberry yellow dwarf) but has so far been detected only in light soils in Scotland.

\section{STRAWBERRY MOSAIC}

Strawberry mosaic (Posnette, 1956), a disease of very limited distribution in England, is known only on plants of the Royal Sovereign variety in the field and has been graft transmitted only to Royal Sovereign in the glasshouse.

The symptoms of the disease are somewhat variable but include stunting, small distorted leaves, basal constrictions and puckering of leaflets accompanied by irregularly distributed yellow areas of variable sizes and shapes.

The disease may be caused by a complex of viruses. In all attempts to transmit the virus by $P$. fragaefolii only the strawberry mottle and crinkle viruses have been transmitted, and the virus (or viruses) responsible for the distinctive symptoms has not been isolated from the others.

\section{Incubation Period}

\section{ANALYSIS OF DATA}

The incubation periods at East Malling of the strawberry viruses 1, 2, 3,4 , and 5 of Prentice were reported by $\operatorname{him}(1949,1952)$ to be, respectively, 2 to 3 weeks, 4 to 6 weeks, 4 to 8 weeks, 3 to 4 weeks, and 4 to 5 weeks. He made use of the differences as a general supporting character in differentiating the viruses. The fact that even under the fairly constant conditions of environment and technique in one laboratory the incubation period of a single strawberry virus will have a rather wide range which may overlap that of other viruses would tend to minimize its potential importance as a specific distinguishing character, and no information has been available to indicate the variance that might occur between two laboratories.

Using data from Table 1 , statistical support $(\mathrm{P}=0.05$ or less) could be found for the following comparisons:

The incubation period for the group of four isolates of the typical form of mottle virus at Berkeley was slightly longer than that of the Berkeley group of four curly-dwarf mottle isolates (mean, in days, plus or minus the standard deviation $=9.2 \pm 2.2$ versus $8.3 \pm 2.45)$.

The incubation period of vein banding virus exceeded that of either typical mottle or curly-dwarf mottle at Berkeley (22.1 \pm 3.7 days).

At East Malling, both the rusty-leaf and typical forms of mottle virus have incubation periods in excess of that of the curly-dwarf form $(15.1 \pm 2$,

\footnotetext{
${ }^{6}$ The statistical analyses using indicated data contained in Tables 1, 2, and 3 are con-
} tributed by Edward S. Sylvester, Department of Entomology, Berkeley. 
$11.3 \pm 3$, and $9.0 \pm 2.6$ days, respectively). The incubation period of rusty leaf was longer than that of mottle.

The two typical mottle virus isolates 1 and 2 were compared at both Berkeley and East Malling. The incubation periods of these two isolates could not be statistically distinguished either in California ( $9.3 \pm 2.2$ versus $9.4 \pm 2.0$ days, respectively) or in England (10.5 \pm 2.5 versus $10.6 \pm 3.4$ days, respectively), but the incubation periods of both were significantly longer in England than in California. The isolates were consistent within each environment.

TABLE 2

RESULTS* OF TESTS ON THE ACQUISITION THRESHOLD PERIOD OF THREE STRAWBERRY VIRUSES FOR PENTATRICHOPUS THOMASI SSP. JACOBI AT BERKELEY

\begin{tabular}{|c|c|c|c|c|c|c|c|}
\hline \multirow{2}{*}{ Virus } & \multirow{2}{*}{$\begin{array}{l}\text { Number of } \\
\text { plants tested } \\
\text { per interval }\end{array}$} & \multicolumn{6}{|c|}{ Acquisition feeding periods in minutes } \\
\hline & & 30 & 40 & 50 & 60 & 90 & 120 \\
\hline Mottle & & \multicolumn{6}{|c|}{ Number of plants infected } \\
\hline $\begin{array}{l}\text { typical form } \\
\text { isolate } 1\end{array}$ & 36 & 0 & 0 & 2 & 1 & 11 & 12 \\
\hline isolate $2 \ldots$ & $\begin{array}{l}50 \\
15\end{array}$ & $\begin{array}{l}0 \\
0\end{array}$ & 0 & $\begin{array}{l}2 \\
1\end{array}$ & $\begin{array}{l}1 \\
2\end{array}$ & $\begin{array}{r}11 \\
5\end{array}$ & 5 \\
\hline isolate $3 \ldots$ & 33 & 0 & 0 & 1 & 4 & 7 & 9 \\
\hline isolate $4 \ldots \ldots \ldots \ldots \ldots \ldots \ldots \ldots \ldots \ldots \ldots$ & 15 & 0 & 0 & 0 & 1 & 9 & 9 \\
\hline curly-dwarf form & & & & & & & \\
\hline isolate $1 \ldots .$. & 6 & 0 & 0 & 0 & 1 & 2 & 3 \\
\hline isolate $2 \ldots \ldots \ldots \ldots \ldots \ldots \ldots \ldots \ldots \ldots$ & 33 & 0 & 0 & 3 & 2 & 7 & 15 \\
\hline isolate $3 \ldots \ldots \ldots \ldots \ldots \ldots \ldots \ldots$ & 30 & 0 & 2 & 2 & 3 & 9 & 18 \\
\hline isolate $4 \ldots \ldots \ldots \ldots \ldots \ldots \ldots \ldots$ & 18 & 0 & 1 & 2 & 1 & 5 & 4 \\
\hline Vein banding $\dagger . . \ldots \ldots \ldots \ldots \ldots \ldots \ldots \ldots$ & 34 & 2 & $\mathrm{~N} \ddagger$ & $\mathrm{N}$ & 1 & 7 & 17 \\
\hline
\end{tabular}

* Three aphids per plant. Alpine test and virus source plants and a minimum test feeding period of seven hours were used.

† From published data.

$\ddagger \mathrm{N}$ indicates that no tests were made.

The above comparisons suggest that the incubation period is a specific character of a virus and even though the expression can be influenced by plant relationships and environment it is a potentially useful character in distinguishing between strawberry viruses.

\section{Acquisition Threshold Period}

The data available (Table 2) are limited, but it appeared of interest to compare graphically the slopes of the virus acquisition curves for the typical and curly-dwarf mottle virus forms and vein banding virus. All the curves were fitted, using the least squares method, to a second degree polynomial of the general form $\mathrm{Y}=\mathrm{a}+\mathrm{bX}+\mathrm{cX^{2 }}$. The theoretical curves are graphically presented in Graph 1. The curves are very similar. Acquisition appears to begin near 30 minutes and continues to rise over the intervals tested (40, $50,60,90$, and 120 minutes) with not much evidence that the slopes are essentially different. The data apply only to the threshold region of the acquisition curves. If data were available to extend the curves over a greater period of acquisition, better comparisons would be permitted between the 


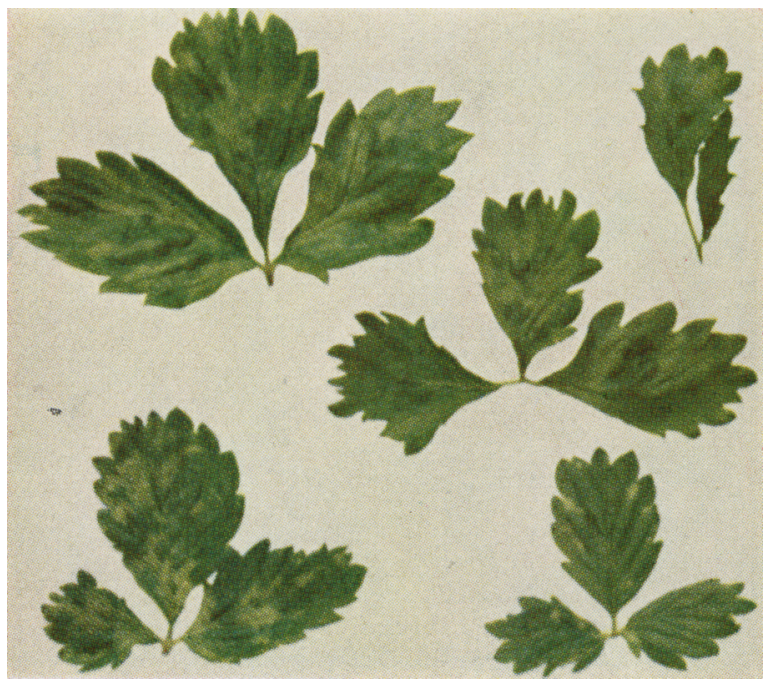

Plate 1. Leaves from Alpine plants infected with curly-dwarf mottle virus isolate 2 after periods of 3 weeks (below) and 6 months (above). (Berkeley) 


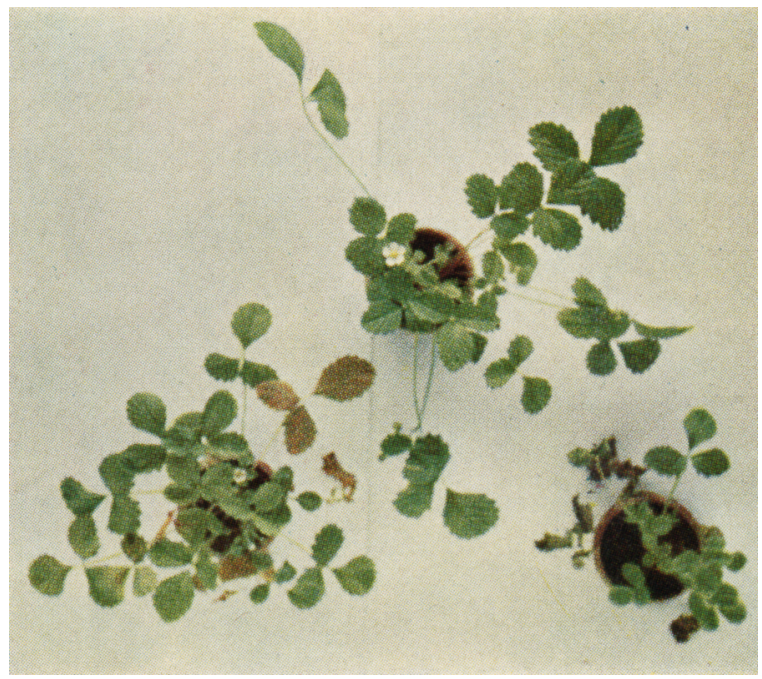

Plate 2. Alpine plants of same age: center, virus free; left, during early, and right, advanced stages of infection with mild yellow-edge virus. Note the premature discoloration and necrosis of the older leaves of the infected plants. (Berkeley) 


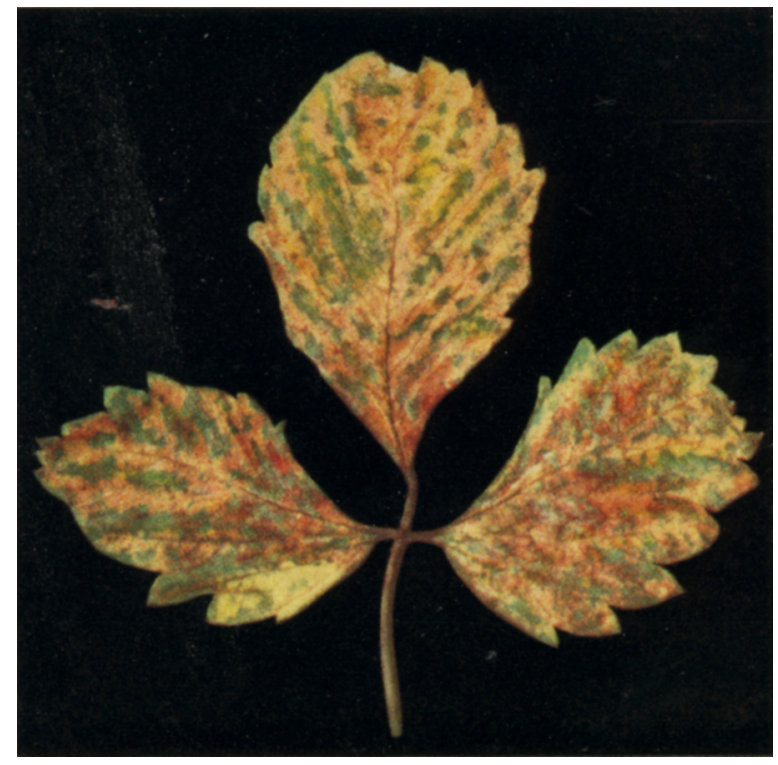

Plate 3. Older leaf from an Alpine plant infected with mild yellow-edge virus showing the mottled discoloration typical of the disease and an early stage of necrosis. (Berkeley) 


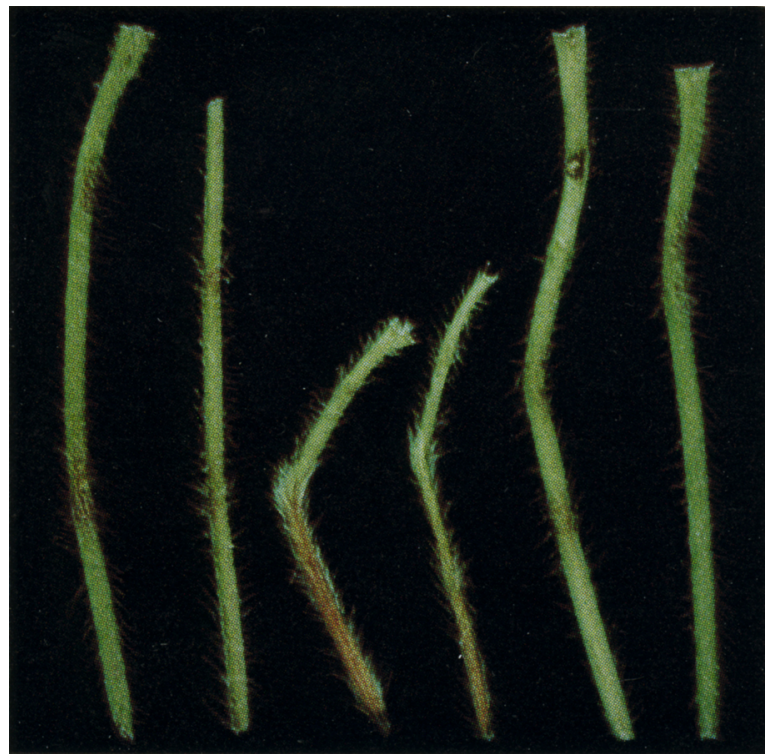

Plate 4. Petioles of leaves from UC-1 plants infected with lesion-A virus showing examples of lesions and their effect in causing crookedness of the petiole. (Berkeley) 


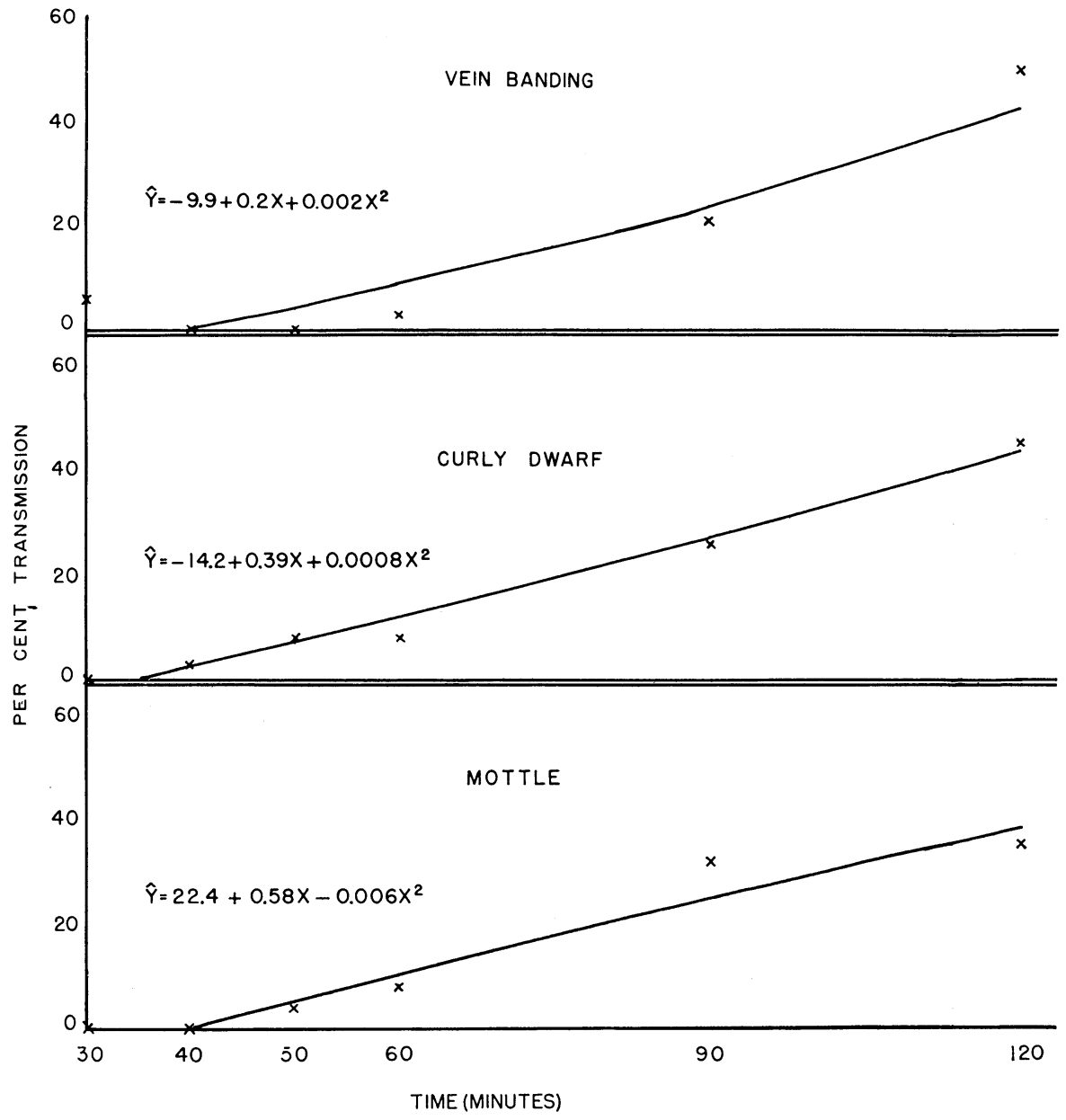

Graph 1. Theoretical curves illustrating the acquisition of the strawberry vein banding, curly-dwarf mottle and mottle viruses by Pentatrichopus thomasi ssp. jacobi at Berkeley.

viruses and also with the theoretical curves calculated for the beet mosaic and beet yellows viruses (Sylvester, 1956b) for which parabolic acquisition curves were hypothesized, even though the curve of beet mosaic was in terms of a time scale of seconds while that of the yellows was in terms of hours. The 30-minute approximate value of the acquisition threshold period of the three strawberry viruses more closely resembles that of beet yellows, about 5 minutes (Watson, 1940), 5 to 10 minutes (Bennett and Costa, 1954), and 1 hour (Sylvester, 1956a), rather than the 5- to 10-second period (Sylvester, 1949) of beet mosaic virus.

\section{Virus Retention by Aphids}

It was assumed that the rate of virus loss by infective aphids is a constant and the transmission effected during any given interval is governed by the 
amount of initial virus charge. Exponential curves were fitted by the least squares method using data presented in Table 3 and the relationship $\hat{Y}=e^{-a t}$, in which $\hat{Y}=$ the probability of obtaining an infection, e is the base of natural logarithms, alpha is a constant, and t represents time (Graphs 2 and 3).

Under the assumptions, the combined data for the four typical mottle isolates at Berkeley indicated that mottle virus has a half-life of approximately 90 minutes, with the initial charge of virus being in excess of that

TABLE 3

RETENTION* OF FIVE STRAWBERRY VIRUSES BY PENTATRICHOPUS FRAGAEFOLII AT EAST MALLING OR P. THOMASI SSP. JACOBI AT BERKELEY

\begin{tabular}{|c|c|c|c|c|c|c|c|c|c|}
\hline \multirow{2}{*}{ Virus } & \multirow{2}{*}{ Isolate and locality $\dagger$} & \multirow{2}{*}{$\begin{array}{c}\text { Number } \\
\text { lots } \\
\text { tested }\end{array}$} & \multicolumn{7}{|c|}{ Successive hourly test feeding periods } \\
\hline & & & 1 & 2 & 3 & 4 & 5 & 6 & $7-24$ \\
\hline \multirow{8}{*}{$\begin{array}{l}\text { Mottle } \\
\text { typical form. }\end{array}$} & & & \multicolumn{7}{|c|}{ Number plants infected } \\
\hline & 1, EM. . & 10 & 9 & 7 & 2 & $\ldots$ & $\ldots$ & 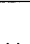 & . \\
\hline & $2, \mathrm{EM} \ldots \ldots \ldots \ldots$ & 90 & 40 & 17 & 9 & 4 & 1 & 2 & .. \\
\hline & $\mathrm{EM} \ddagger \ldots \ldots \ldots \ldots$ & 105 & 82 & 48 & 24 & 6 & 1 & 3 & .. \\
\hline & $1, B, \ldots \ldots \ldots \ldots \ldots$ & 59 & 47 & 45 & 27 & 17 & 10 & 3 & .. \\
\hline & $2, \mathrm{~B} \ldots \ldots \ldots \ldots \ldots \ldots \ldots$ & 11 & 9 & 7 & 5 & 3 & 2 & 1 & .. \\
\hline & $3, \mathrm{~B} \ldots \ldots \ldots \ldots \ldots \ldots \ldots$ & 33 & 22 & 19 & 16 & 5 & 4 & 2 & . \\
\hline & $4, \mathrm{~B}, \ldots \ldots \ldots \ldots \ldots \ldots$ & 15 & 15 & 14 & 13 & 7 & 3 & 2 & .. \\
\hline \multirow[t]{5}{*}{ curly-dwarf form. } & EM. . & 30 & 29 & 14 & 6 & 1 & .. & .. & .. \\
\hline & $1, \mathrm{~B} \ldots \ldots$ & 6 & 6 & 2 & 1 & .. & .. & .. & .. \\
\hline & $2, \mathrm{~B} \ldots \ldots$ & 33 & 24 & 10 & 3 & 1 & . & .. & .. \\
\hline & $3, \mathrm{~B} \ldots$ & 30 & 24 & 14 & 3 & . & .. & .. & .. \\
\hline & $4, \mathrm{~B} \ldots \ldots \ldots \ldots \ldots \ldots \ldots$ & 18 & 13 & 5 & 3 & 1 & . & .. & .. \\
\hline rusty-leaf form... & EM.... & 20 & 7 & . & .. & .. & . & .. & .. \\
\hline Leaf-curl & $\mathrm{EM} \ldots \ldots \ldots \ldots \ldots \ldots$ & 10 & 6 & 1 & . & . & . & . & .. \\
\hline Vein banding§ & $\mathrm{B} \ldots \ldots \ldots \ldots \ldots \ldots \ldots \ldots$ & 38 & 11 & 14 & 14 & 11 & 3 & . & .. \\
\hline
\end{tabular}

* Individual lots of three aphids. Alpine test plants and an acquisition feeding period of 20 hours were used. t EM indicates East Malling; $B$ indicates Berkeley.

$\ddagger$ Transmissions from eight virus sources excluding isolates 1 and 2.

From published data.

required to cause 100 per cent infection. The half-life of mottle isolates 1 and 2 together was calculated to be about 87 minutes at Berkeley with an initial virus charge in excess of that sufficient to cause over 100 per cent infection, but only 50 minutes at East Malling and an initial virus charge sufficient to cause about 80 per cent infection (Graph 3 ). This great difference in the half-life values of the same virus in two laboratories casts reasonable doubt upon whether the rate of virus decay in, or loss by, infective aphids is solely a property of the virus alone. If such were the case one would expect comparable results in any laboratory. In the present instance, one of the factors that may have influenced the half-life values was the difference in vectors used ( $P$. fragaefolii at East Malling and $P$. $t$. jacobi at Berkeley). It may be that any assumption of a constant rate of virus loss by infective aphids must be qualified as to the species of aphid if the half-life is to be used as a comparative value. 
Taken together, the four curly-dwarf mottle isolates at Berkeley had a half-life of about 50 minutes and an initial charge of virus sufficient to cause about 75 per cent infectivity.

Vein banding virus at Berkeley was the least stable of the viruses with an estimated half-life of approximately 30 minutes. This was the least satisfactory datum to handle, for only two points could be utilized to estimate the rate of decline, viz., the percentage transmission during the fourth and fifth hours after acquisition. If the present interpretation is justified, it would

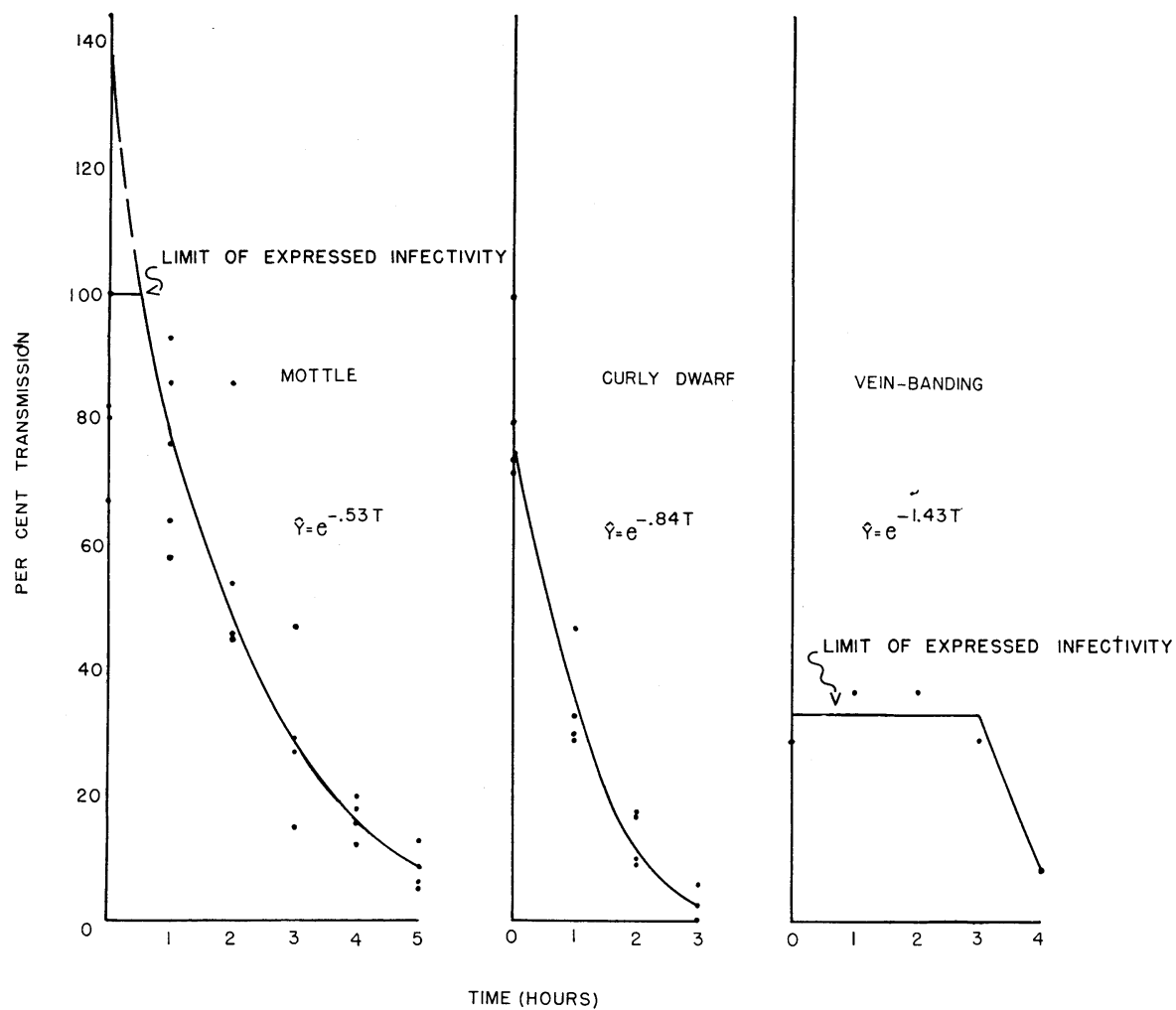

Graph 2. Theoretical curves illustrating the retention of the strawberry mottle, curly-dwarf mottle and vein banding viruses by Pentatrichopus thomasi ssp. jacobi at Berkeley.

appear that the amount of vein banding virus potentially expressible is far in excess of that which can actually cause infection. A possible explanation of the results might be that only a few insects became infective, but those that did acquired a high virus charge, the loss of which would not be detected until something in excess of six half-lives had passed, but there is insufficient evidence to support such an hypothesis.

Sylvester (1956a) reported a half-life of five minutes in the green peach aphid for the beet mosaic virus compared with eight hours for beet yellows, neither of which is within the range of those of the three strawberry viruses reported here. It appears that the rate of virus loss during retention trials 


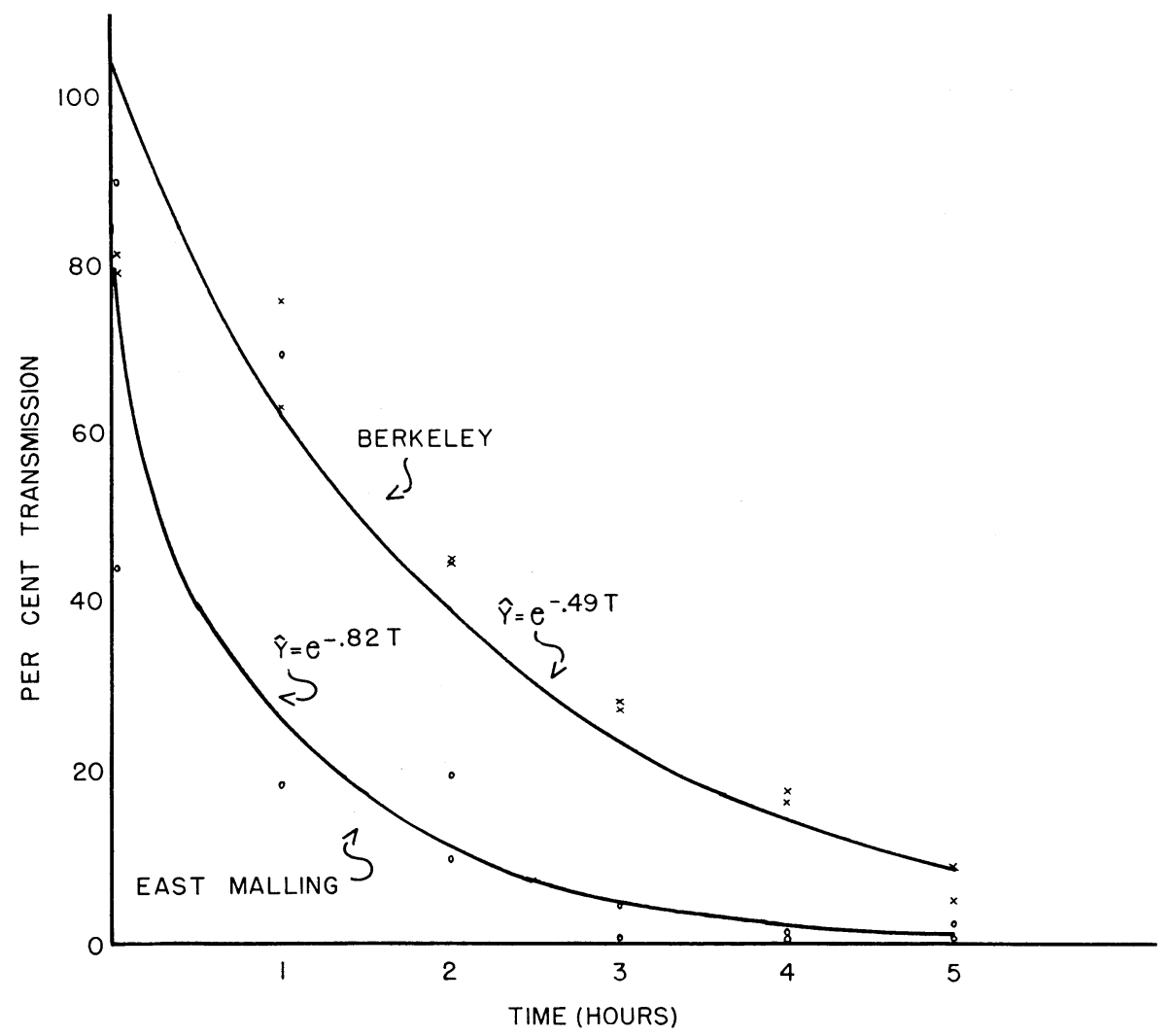

Graph 3. Theoretical curves illustrating retention of the strawberry mottle virus by Pentatrichopus fragaefolii at East Malling and $P$. thomasi ssp. jacobi at Berkeley.

would be a useful supporting character in separating otherwise closely related viruses or virus groups, particularly if the comparisons were made under constant conditions.

\section{DISCUSSION}

The results of the present study have partially clarified the relations of the strawberry viruses of California to those of England. Unsolved problems were encountered concerning the viruses themselves.

The viruses endemic to Britain and California are remarkably similar. The three aphid-transmitted viruses most important in both localities are mottle, mild yellow-edge, and crinkle. The leaf-curl viruses, also aphidtransmitted (Tables 5 and 6), appear to be a North American group of minor importance in California and of no importance in Britain. One leafhopper-transmitted virus is known in each of the two areas: green petal in Britain and aster yellows in California. The symptoms of these viruses are similar and both are occasionally responsible for important losses. There are other viruses or virus complexes known in England or California but for which no vectors have been determined. 
TABLE 4

TRANSMISSION OF STRAWBERRY MILD YELLOW-EDGE VIRUS AT EAST MALLING BY PENTATRICHOPUS FRAGAEFOLII TO F. VESCA (EAST MALLING CLONE)

\begin{tabular}{|c|c|c|c|c|c|c|c|c|c|c|c|}
\hline \multirow{2}{*}{$\begin{array}{c}\text { Test } \\
\text { number }\end{array}$} & \multirow{2}{*}{$\begin{array}{l}\text { Acquisition feeding } \\
\text { period (days) }\end{array}$} & \multirow{2}{*}{$\begin{array}{l}\text { Number } \\
\text { aphids } \\
\text { per lot }\end{array}$} & \multirow{2}{*}{$\begin{array}{c}\text { Number } \\
\text { lots } \\
\text { tested }\end{array}$} & \multicolumn{8}{|c|}{ Serial test feeding periods, days } \\
\hline & & & & $1 / 4$ & 1 & 1 & 2 & 3 & 4 & 10 & 16 \\
\hline & & & & \multicolumn{8}{|c|}{ Number plants infected } \\
\hline 1 & $3 \ldots \ldots \ldots \ldots \ldots \ldots \ldots$ & 6 & 10 & 0 & 0 & $\bullet *$ & 4 & $\bullet$ & 6 & $\bullet$ & $\bullet$ \\
\hline 2 & $5 \ldots \ldots \ldots \ldots \ldots \ldots \ldots \ldots$ & 5 & 20 & 2 & 1 & $\bullet$ & $\bullet$ & $\bullet$ & 13 & $\bullet$ & • \\
\hline 3 & $7 \ldots \ldots \ldots \ldots \ldots$ & 10 & 10 & 0 & 2 & $\bullet$ & $\bullet$ & $\bullet$ & 4 & $\bullet$ & $\bullet$ \\
\hline 4 & $9 \ldots \ldots \ldots \ldots$ & 10 & 10 & $\bullet *$ & 0 & - & 1 & $\bullet$ & 5 & $\bullet$ & $\bullet$ \\
\hline 5 & reared........ & 15 & 40 & $\bullet$ & 7 & $\bullet$ & 17 & $\bullet$ & $\bullet$ & $\bullet$ & $\bullet$ \\
\hline 6 & $14 \ldots \ldots \ldots \ldots \ldots$ & 20 & 10 & 0 & 0 & 2 & $\bullet$ & $\bullet$ & $\bullet$ & 6 & $\bullet$ \\
\hline 7 & reared $\ldots \ldots \ldots$ & 10 & 20 & 3 & 3 & 2 & 1 & 0 & $\bullet$ & 5 & $\bullet$ \\
\hline 8 & reared $\ldots \ldots \ldots$ & 10 & 10 & $\bullet$ & $\bullet$ & $\bullet$ & $\bullet$ & $\bullet$ & $\bullet$ & $\bullet$ & 8 \\
\hline
\end{tabular}

Transmission by the individual lots of aphids transmitting in test No. 7

\begin{tabular}{|c|c|c|c|c|c|c|c}
+ & + & - & - & - & $\bullet$ & + & $\bullet$ \\
- & - & - & - & - & $\bullet$ & + & $\bullet$ \\
+ & - & - & - & - & $\bullet$ & + & $\bullet$ \\
- & - & + & + & - & $\bullet$ & - & $\vdots$ \\
- & + & - & - & - & $\bullet$ & - & $\vdots$ \\
+ & - & - & - & - & $\bullet$ & + & $\vdots$ \\
- & + & - & - & - & $\bullet$ & - & $\vdots$
\end{tabular}

* The period indicates that no test was made; the plus sign that the test plant was infected and the minus sign that the test plant was not infected.

TABLE 5

VECTOR-VIRUS-PLANT RELATIONSHIPS* OF APHID TRANSMITTED STRAWBERRY VIRUSES

\begin{tabular}{|c|c|c|c|c|}
\hline Virus & $\begin{array}{c}\text { Mode } \\
\text { incubation } \\
\text { periods } \\
\text { (days) }\end{array}$ & $\begin{array}{l}\text { Acquisition } \\
\text { threshold } \\
\text { period }\end{array}$ & $\begin{array}{c}\text { Virus } \\
\text { retention }\end{array}$ & $\begin{array}{l}\text { Resistance } \\
\text { to thermal } \\
\text { inactivation }\end{array}$ \\
\hline 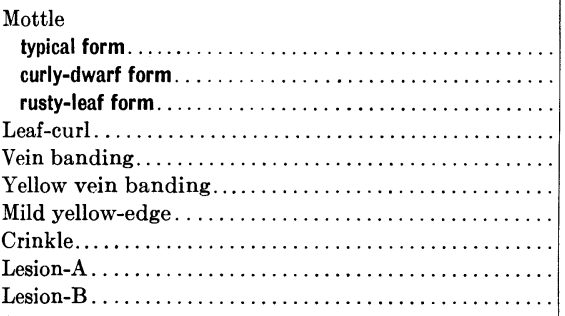 & $\begin{array}{c}8-10 \\
6-8 \\
15 \\
36 \\
18 \\
28 \\
28-42 \\
10 \\
\text { c. } 16 \\
\text { c. } 16\end{array}$ & $\begin{array}{l}\text { c. } 50 \mathrm{~min} \\
\text { c. } 40 \mathrm{~min} \\
\ldots \ldots \ldots \\
\text { c. } 60 \mathrm{~min} \\
\text { c. } 30 \mathrm{~min} \\
\ldots \ldots \ldots \\
\text { c. } 8 \mathrm{hrs} \\
\text { c. } 24 \mathrm{hrs} \\
\ldots \ldots \ldots \\
\ldots \ldots \ldots\end{array}$ & $\begin{array}{c}<6 \mathrm{hrs} \\
<4 \mathrm{hrs} \\
<1 \mathrm{hr} \\
<2 \mathrm{hrs} \\
<5 \mathrm{hrs} \\
\ldots \ldots . \\
>12 \text { days } \\
\quad \text { long } \dagger \\
\ldots \ldots \\
\ldots \ldots\end{array}$ & $\begin{array}{c}\text { low } \\
\text { low } \\
\ldots \ldots \\
\ldots \ldots \\
\text { high } \\
\ldots \ldots \\
\text { high } \\
\text { high } \\
\ldots \ldots \\
\ldots \ldots\end{array}$ \\
\hline
\end{tabular}

* The italicized data were reported by Prentice.

$\dagger$ A latent period of 12 to 16 days must be completed before the virus can be transmitted by the vector. 
The Royal Sovereign and $F$. vesca clones used at East Malling appeared to be universally infected with strawberry latent-A virus so that the symptoms of the viruses described by Prentice were those of virus complexes. Since the presence of latent-A in a plant may appreciably alter the expression of symptoms of some of the other strawberry viruses, the symptoms have been redescribed for the mottle, leaf-curl, mild yellow-edge, and crinkle viruses on presumably virus-free Alpine or UC-1 plants after infection by aphids. The data given by Prentice on vector relationships do not appear to have been influenced by the presence of latent-A virus so his names for the viruses have been retained.

The symptoms of the mottle, leaf-curl, mild yellow-edge, and crinkle viruses were quite distinctive and formed four well-defined types of symptoms. The viruses, however, were similar in that each appeared to be represented by numerous reproduceable variants, the symptoms of which intergraded to form a spectrum. This was especially true in the case of mottle virus, but probably only because it is the most easily transmitted and therefore more variants have been isolated. A new isolate of any of the four viruses could not with certainty be identified with any previous isolate. Interpretation of the symptom spectra is made difficult because strawberry viruses do not lend themselves to many of the tests commonly used for other viruses. The only comparative tests thus far applicable to strawberry viruses consist of symptomatology in a narrow range of Fragaria, vector-virus host relationships and resistance to thermal inactivation in vivo.

In addition to distinctive symptoms (Table 6) mottle, leaf-curl, mild yellow-edge, and crinkle are also characterized by distinctive vector-virus-host relations and differences in resistance to thermal inactivation (Table 5). However, the results of tests with distinctive isolates of the mottle and leafcurl viruses indicated that the relationships may vary with, but be consistent for, different isolates of a virus. The variations between rusty-leaf and typical mottle and between vein banding and leaf-curl viruses were relatively large but a study of other isolates might reveal intergrades. Present information does not clearly establish the level of relationships of the different isolates of the four viruses. The viruses might well represent four groups of distinct viruses rather than groups of related strains.

Other than the four aphid-borne viruses, which have been studied in virusfree test plants, and the two viruses with leafhopper vectors, there are viruses or virus diseases which have been reported but which do not appear to have been studied in virus-free indicator plants after transmission by vectors, so their relationships to other strawberry viruses cannot be determined. The mosaic, vein chlorosis, $\mathrm{X}$, latent-A, and latent-B viruses have already been discussed and their probable relationships indicated. Strawberry stunt and witches'-broom seem not to have been further investigated since they were originally reported in Oregon. Strawberry latent-C and droop are very similar or synonymous and, with leaf-roll and multiplier plant, are known only in areas east of the Rocky Mountains.

Interestingly, the viruses that have been reported from eastern North America appear to constitute a complex quite different from those found either in Great Britain or in the Pacific Coast states. The most prevalent 
viruses in both of the latter two regions are mottle, mild yellow-edge, and crinkle while on the Pacific Coast vein banding is also commonly found, but of these four viruses only mottle is known to occur in the eastern states. In addition, the eastern multiplier plant disease may be related to the Oregon witches'-broom disease. It seems surprising that the viruses established in Great Britain, presumably having been introduced there from America, should be more closely related to the Pacific Coast viruses than to those of the eastern United States. It is even more difficult to explain the apparent differences between the Pacific Coast and eastern virus complexes considering the great amount of interchange of strawberry plant material, including nursery stock, that has taken place between the two regions for many years.

TABLE 6

PRINCIPAL SYMPTOMS* OF APHID TRANSMITTED STRAWBERRY VIRUSES

\begin{tabular}{|c|c|c|}
\hline Virus & Primary symptoms & Chronic symptoms \\
\hline \multicolumn{3}{|l|}{ Mottle } \\
\hline typical form.................. & Vein clearing & Mottle, slight leaf distortion \\
\hline curly-dwarf form. & Vein yellowing & Mosaic, leaf distortion \\
\hline rusty-leaf form.. & Slight vein clearing & Marginal necrosis of older leaves \\
\hline Leaf-curl..... & Diffuse vein banding & Diffuse vein banding \\
\hline Vein banding..... & Conspicuous vein banding & Conspicuous vein banding \\
\hline Yellow vein banding. & Inconspicuous vein clearing & Conspicuous vein banding \\
\hline Mild yellow-edge...$\ldots \ldots \ldots \ldots \ldots$ & Vein clearing or spotting & $\begin{array}{l}\text { Necrotic spotting, yellowing and ne- } \\
\text { crosis of older leaves }\end{array}$ \\
\hline Crinkle.... & $\begin{array}{l}\text { Epinasty; angular crooking of mid- } \\
\text { ribs; lesions }\end{array}$ & $\begin{array}{l}\text { Opaque vein yellowing and spotting; } \\
\text { lesions; leaf distortion }\end{array}$ \\
\hline Lesion-A..................... & $\begin{array}{l}\text { Angular crooking of midribs; } \\
\text { lesions }\end{array}$ & Infrequent lesions \\
\hline Lesion-B..... & $\begin{array}{l}\text { Angular midrib crooking; faint } \\
\text { vein chlorosis; lesions }\end{array}$ & $\begin{array}{l}\text { Infrequent lesions; chlorotic vein } \\
\text { spotting }\end{array}$ \\
\hline
\end{tabular}

* Symptoms induced in Alpine indicator plants except for the leaf-curl virus and the chronic symptoms of the lesion-A and lesion-B viruses which are in the UC-1 clone. 


\section{LITERATURE CITED}

Bennett, C. W., and A. S. Costa

1954. Observations and studies of virus yellows of sugar beet in California. Amer. Soc. Sugar Beet Technol. Proc. 8:230-35.

Berkeley, G. H., and A. G. Plakidas

1942. Strawberry leaf roll, a new disease. Phytopathology 32:631-33.

Cadman, C. H.

1956. Studies on the etiology and mode of spread of Scottish raspberry curl disease. Jour. Hort. Sci. 31:111-18.

Demaree, J. B., and C. P. Marcus

1951. Virus diseases of strawberries in the United States, with special reference to distribution, indexing, and insect vectors in the East. U. S. Dept. Agr. Pl. Dis. Rptr. 35:527-37.

DuFrus, J. E.

1956. Host and vector relationships of strawberry viruses in Wisconsin. (Abstract) Summaries of Doctoral Dissertations, University of Wisconsin, 1954-1955, 16: 141-43.

Fitzpatrick, R. E., and Frances C. Mellor

1951. Studies of virus diseases of strawberries in British Columbia. I. The reaction of the British Sovereign variety and the indicator Fragaria vesca to yellows. Canad. Jour. Bot. 29:182-88.

Frazier, N. W.

1951. New aphid vectors of strawberry viruses. Jour. Econ. Ent. 44:258.

1953. A latent virus of Fragaria vesca. U. S. Dept. Agr. Pl. Dis. Rptr. 37:606-08.

1955a. Tobacco necrosis virus on strawberry. U. S. Dept. Agr. Pl. Dis. Rptr. 39:143-47.

1955b. Strawberry vein banding virus. Phytopathology 45:307-12.

Frazier, N. W., and A. F. PosnetTe

1956. Leafhopper transmission of a clover virus causing green petal disease in strawberries. Nature (London) $177: 1040-41$.

1957. Transmission and host range studies of strawberry green petal virus. Ann. Appl. Biol. 45:580-88.

Frazier, N. W., and H. E. Thomas

1953. Strawberry a host of Western aster yellows virus. U. S. Dept. Agr. Pl. Dis. Rptr. 37:272-75.

Fulton, J. P.

1952. A tobacco necrosis virus associated with strawberry plants. U. S. Dept. Agr. Pl. Dis. Rptr. 36:313-14.

1957. Aster yellows virus affecting strawberries in Arkansas. U. S. Dept. Agr. Pl. Dis. Rptr. 41:521-23.

GOURLEY, C. O.

1955. Green petal of strawberry in Nova Scotia. U. S. Dept. Agr. Pl. Dis. Rptr. 39: 808-09.

HARRIS, R. V.

1932. Grafting as a method for investigating a possible virus disease of the strawberry. Jour. Pomol. and Hort. 10:35-41.

1933. The strawberry "yellow-edge" disease. Jour. Pomol. and Hort. Sci. 11:56-76.

1937a. Virus diseases in relation to strawberry cultivation in Great Britain. A synopsis of recent experiments at East Malling. East Malling Res. Sta. Ann. Rpt. for 1936:201-11.

1937b. Studies in strawberry virus diseases. III. Transmission experiments with crinkle. East Malling Res. Sta. Ann. Rpt. for 1936:211-21.

HARRIS, R. V. and MARY E. KING

1942. Studies in strawberry virus diseases. V. The use of Fragaria vesca L. as an indicator of yellow-edge and erinkle. Jour. Pomol. and Hort. Sci. 19:227-42.

HARRISON, B. D.

1958. Raspberry yellow dwarf a soil-borne virus. Ann. Appl. Biol. (In press.) 
Hille Ris Lambers, D.

1953. Contributions to a monograph of the Aphididae of Europe. Part V. Temminckia IX: $1-176$.

HORNE, W. T.

1922. Strawberry troubles. California Agr. Exp. Sta. Rpt. 1921-1922:122-23.

LISTER, R. M.

1958. Soil-borne virus diseases of strawberry. Plant Pathology. (In press.)

McGRew, J. R.

1956. Analysis of viruses causing Demaree and Marcus type 1 and type 2 symptoms in Fragaria vesca. U. S. Dept. Agr. Pl. Dis. Rptr. 40:173-75.

Mellor, Franceis C., and R. E. Fitzpatrick

1951. Studies of virus diseases of strawberries in British Columbia. II. The separation of the component viruses of yellows. Canad. Jour. Bot. 29:411-20.

Ogilvie, L., T. SWARBrick, and C. R. THompson

1934. A note on a strawberry disease resembling the American crinkle. Long Ashton Res. Sta. Ann. Rpt. for 1933:96-97.

Plakidas, A. G.

1926. Strawberry "yellows," a degeneration disease of the strawberry. Phytopathology $16: 423-26$.

1927. Strawberry Xanthosis (yellows), a new insect-borne disease. Jour. Agr. Res. 35:1057-90.

- 1951. Chlorotic phyllody of strawberry. U. S. Dept. Agr. Pl. Dis. Rptr. 35:495-96.

PosNeTte, A. F.

1952., New vectors of strawberry viruses. Nature (London) 169:837-38.

1953a. Heat inactivation of strawberry viruses. Nature (London) 171:312-13.

1953b. Green petal-a new virus disease of strawberries. Plant Pathology 2:17-18.

1956. Strawberry mosaic virus disease. East Malling Res. Sta. Ann. Rpt. for 1955:120.

Posnette, A. F., R. Cropley, and Christina E. Ellenberger

1953. Progress in the heat treatment for strawberry virus diseases. East Malling Res. Sta. Ann. Rpt. for 1952:128-30.

PRENTiCE, I. W.

1948. Resolution of strawberry virus complexes. II. Virus 2 (mild yellow-edge virus). Ann. Appl. Biol. 35:279-89.

1949. Resolution of strawberry virus complexes. III. The isolation and some properties of virus 3. Ann. Appl. Biol. 36:18-25.

1952. Resolution of virus complexes. V. Experiments with viruses 4 and 5. Ann. Appl. Biol. $39: 487-94$.

PRENTICE, I. W., and R. V. HARris

1946. Resolution of strawberry virus complexes by means of the aphis vector Capitophorus fragariae Theob. Ann. Appl. Biol. 33:50-53.

Prentice, I. W., and TAmsyn M. Woollcombe

1951. Resolution of strawberry virus complexes. IV. The latent period of virus 3 in the vector. Ann. Appl. Biol. 38:389-94.

Sмiтн, H. E.

1954. New strawberry disease in Arkansas. U. S. Dept. Agr. Pl. Dis. Rptr. 38:630-31. SYLVESTER, E. S.

1949. Beet mosaic virus-green peach aphid relationships. Phytopathology 39:417-424.

$1956 a$. Beet yellows virus transmission by the green peach aphid. Jour. Econ. Ent. 49:789-800.

$1956 b$. Beet mosaic and beet yellows virus transmission by the green peach aphid. Jour. Amer. Soc. Sugar Beet Technol. 9:56-61.

Thomas, H. E.

1949. The strawberry virus complex. (Abs.) Phytopathology 39:863.

VAUGHAN, E. K.

1933. Transmission of the "Crinkle" disease of strawberry. Phytopathology 23:738-40.

Watson, M. A.

1940. Studies on the transmission of the sugar beet yellows virus by the aphis, Myzus persicae (Sulz.). Proc. Roy. Ent. Soc. London, Ser. B, 123:535-52. 
ZELLER, S. M.

1927. Preliminary studies on witches'-broom of strawberry. Phytopathology 17:329-35.

1933. Crinkle disease of strawberry. Oregon Agr. Exp. Sta. Bul. 319. 14 pp.

ZELLER, S. M., and E. K. VAUGHAN

1932. Crinkle disease of strawberry. Phytopathology 22:709-13.

ZELLER, S. M., and L. E. WEAVER

1941. Stunt disease of strawberry. Phytopathology 31:849-51. 


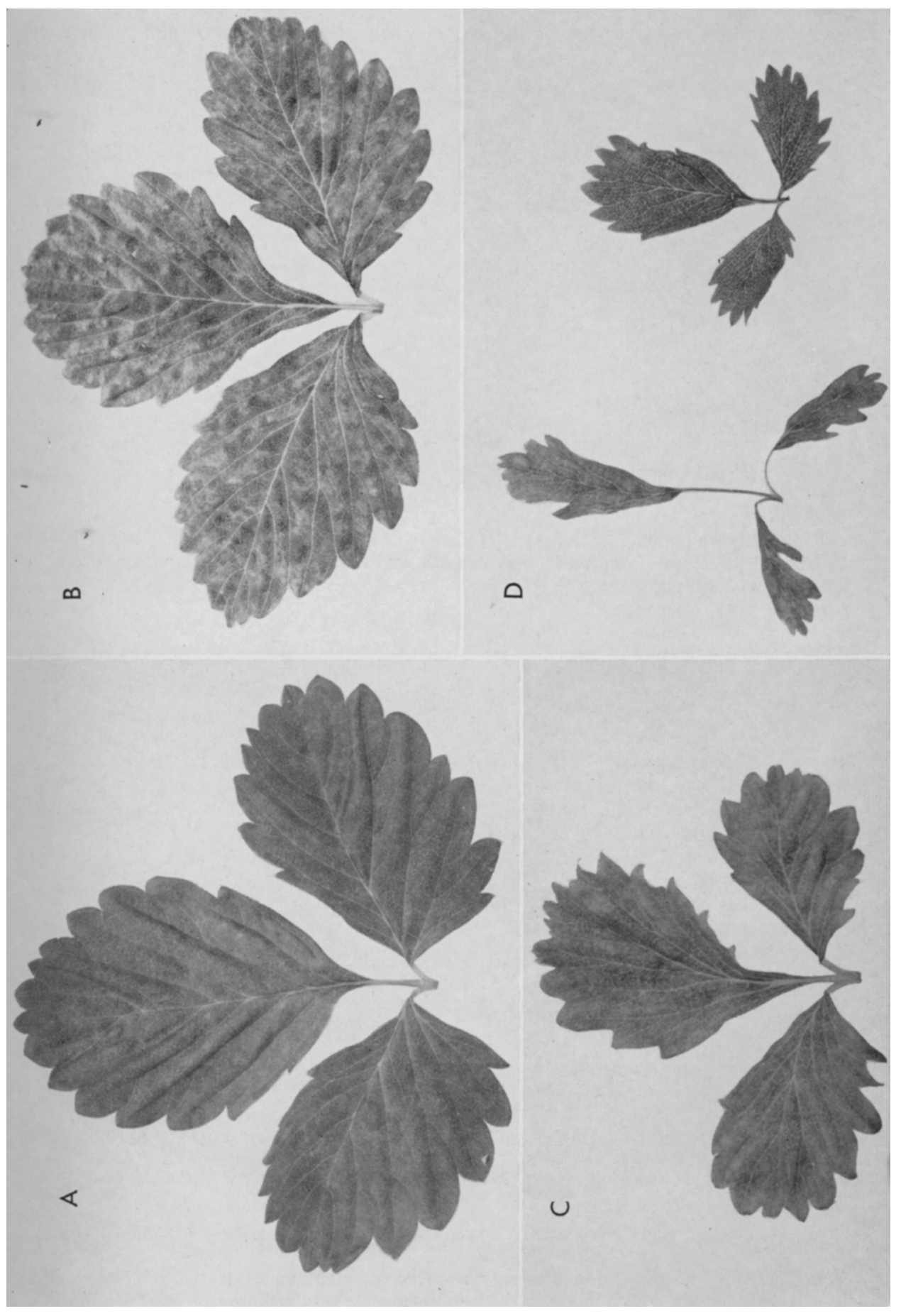

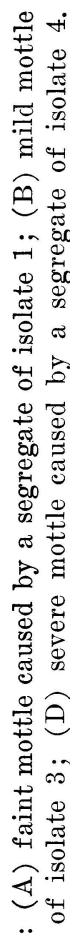

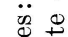

政

$\stackrel{\varpi}{\oplus}$

o

若

ये

. 71

.

营賕

4

范

है

50

ㅇ․․

음

믈

旅

.

궁

ㅎํ요

고용

sio

压 


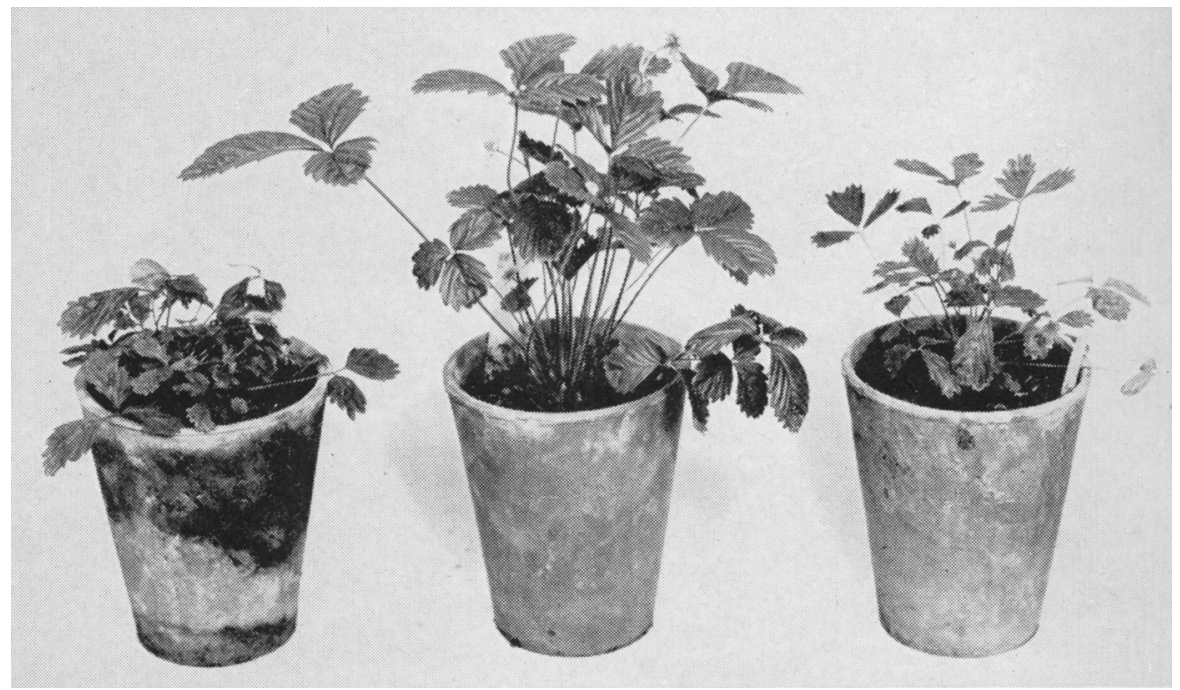

Fig. 2. Alpine plants infected by: left, curly-dwarf mottle virus; center, a mottle virus isolate causing faint symptoms; right, mottle virus isolate 1 causing intermediate symp. toms. (East Malling)

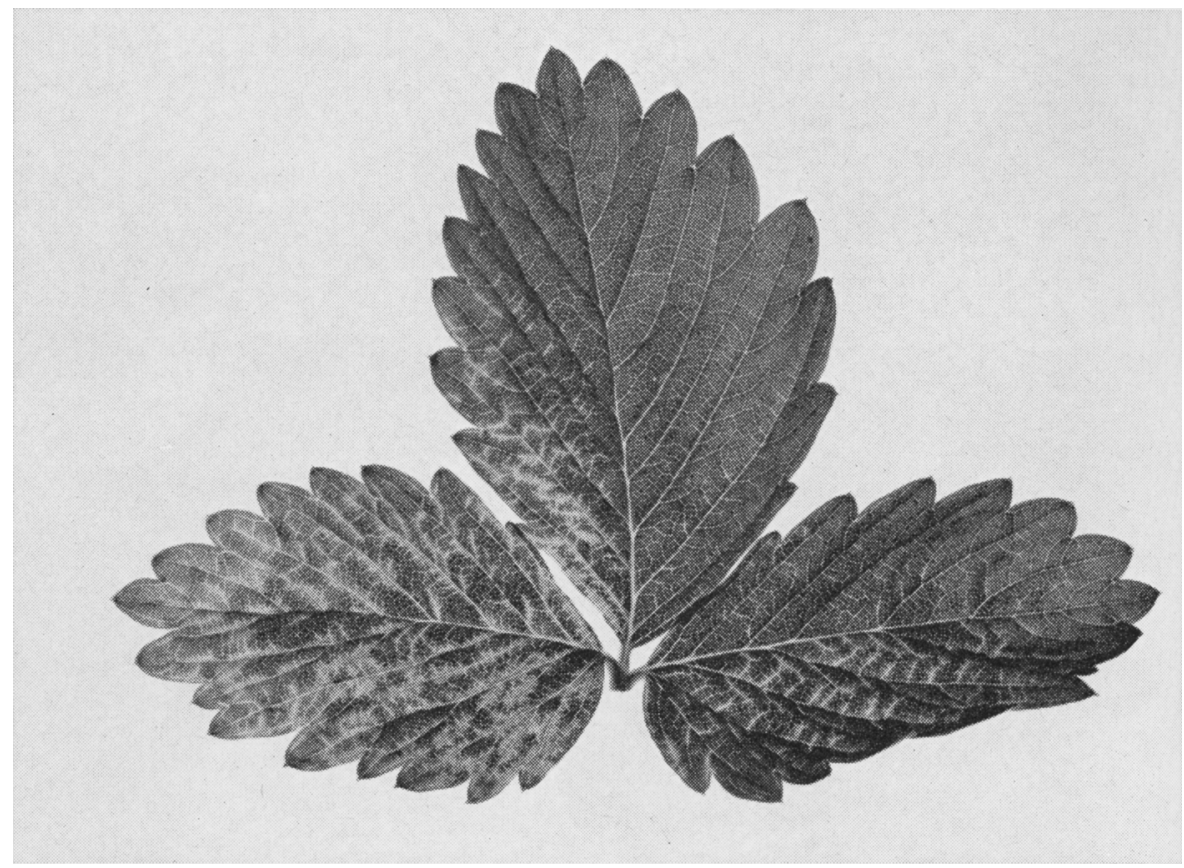

Fig. 3. Young leaf of Alpine showing the primary symptom of cleared veinlets resulting from infection with a mottle virus isolate causing mild symptoms. (East Malling) 


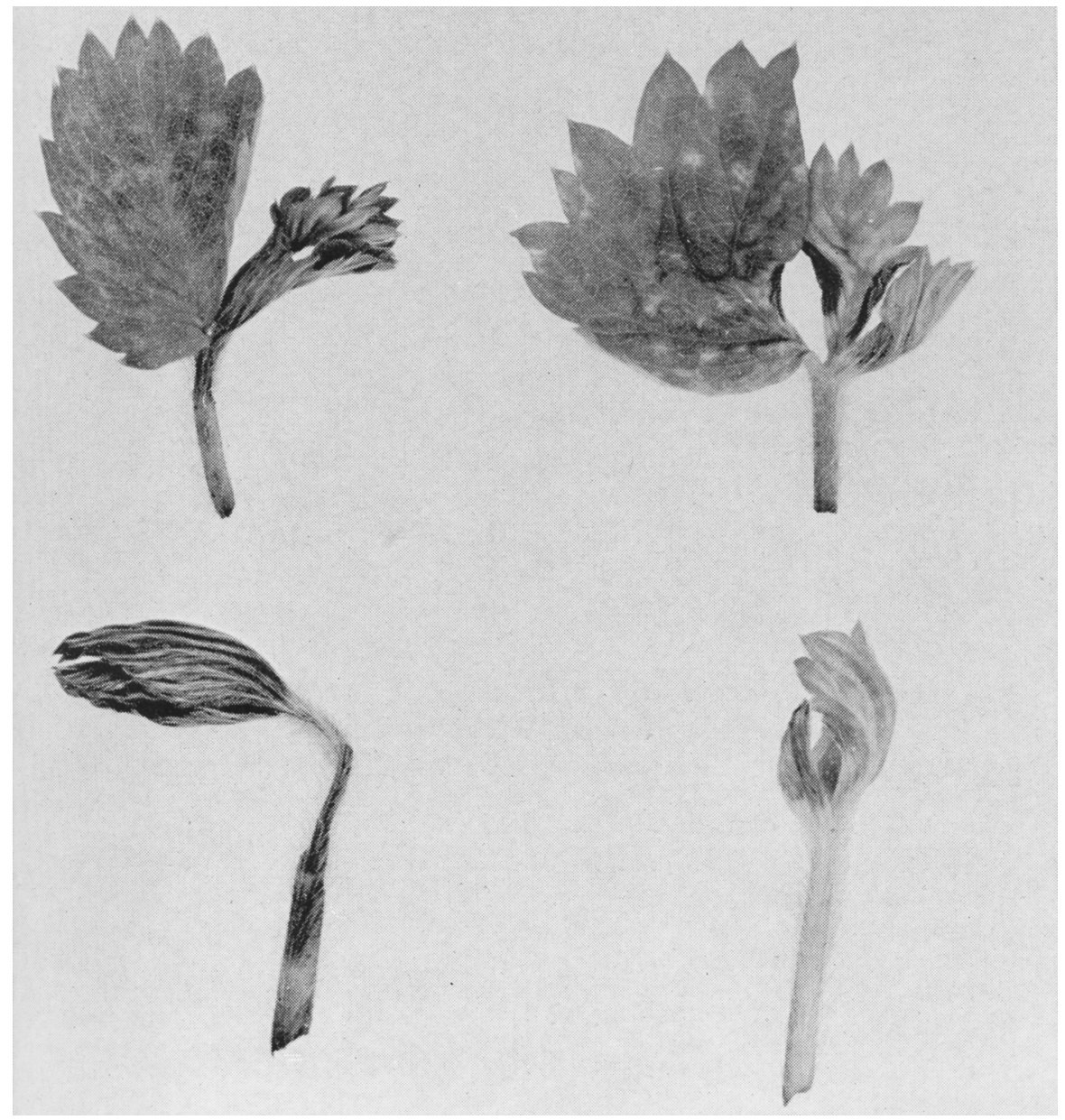

Fig. 4. Young leaves from plants of the latent-A virus infected East Malling clone showing shock symptoms of necrosis and malformation resulting from additional infection with mottle virus isolate 2 . (Berkeley) 


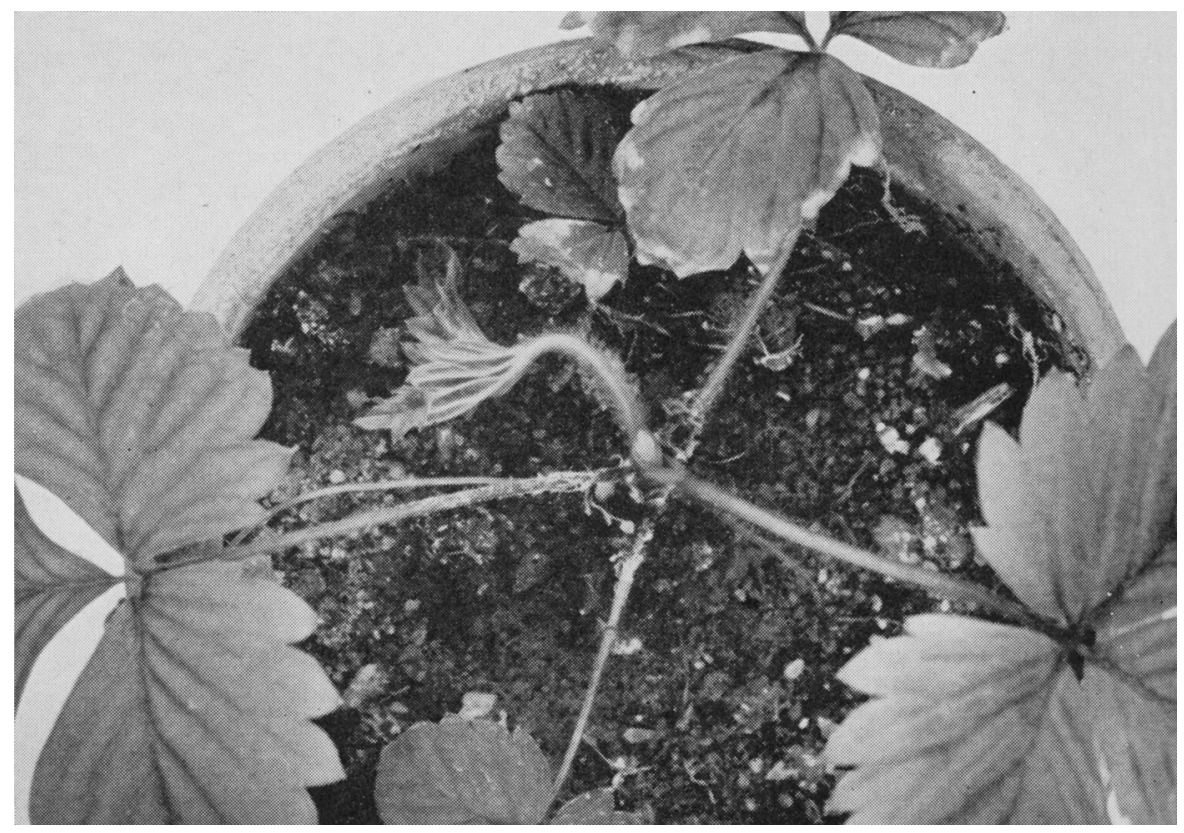

Fig. 5. Alpine plant showing primary symptoms of epinasty of the petiole and delayed expansion of the leaflets of the youngest leaf resulting from infection with a mottle virus isolate causing intermediate symptoms. (East Malling) 


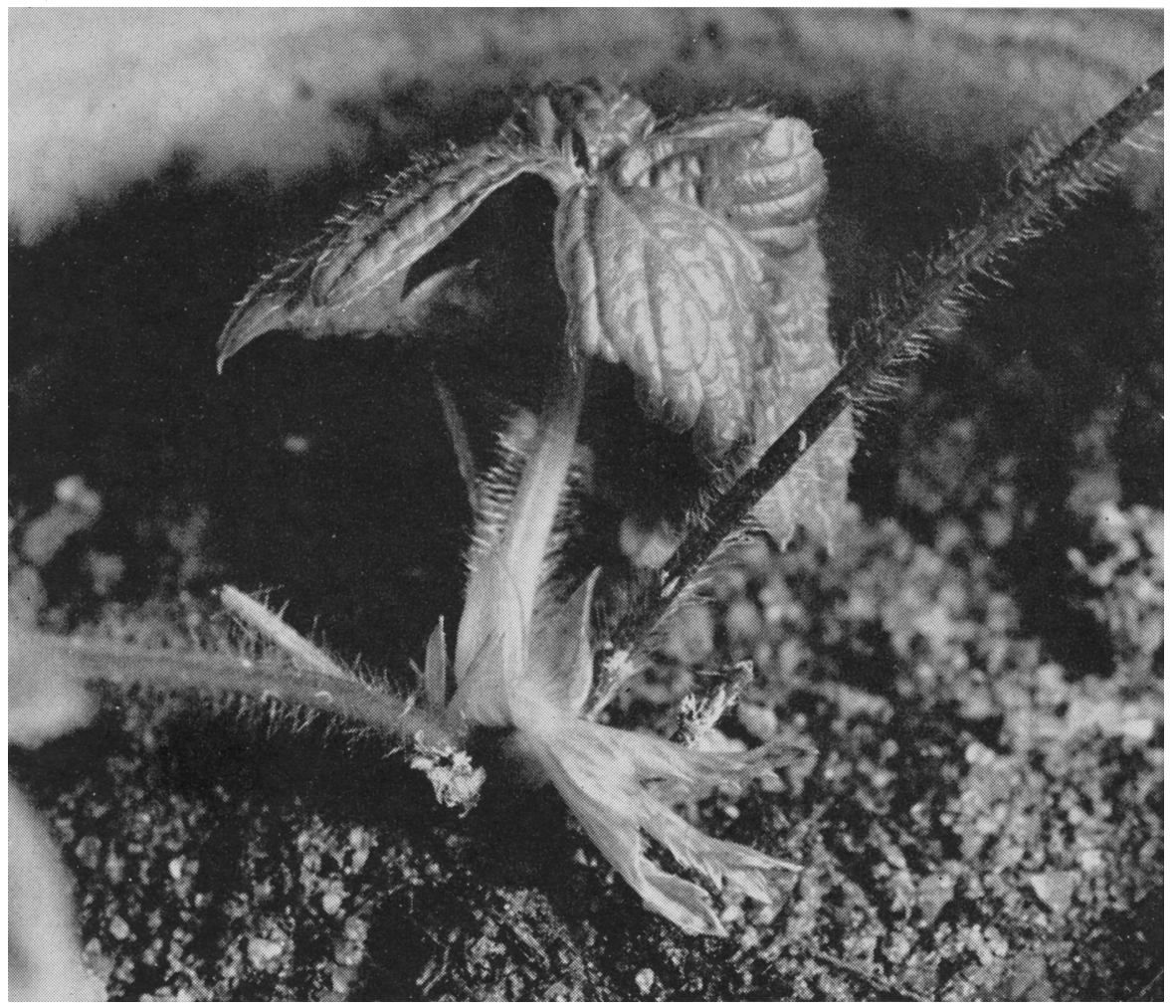

Fig. 6. Crown of Alpine plant infected with a mottle virus isolate causing severe symptoms showing outward rolling of the leaflets and epinasty of the petiole of the first leaf to show symptoms and epinasty and chlorosis of the succeeding or youngest leaf. (East Malling) 


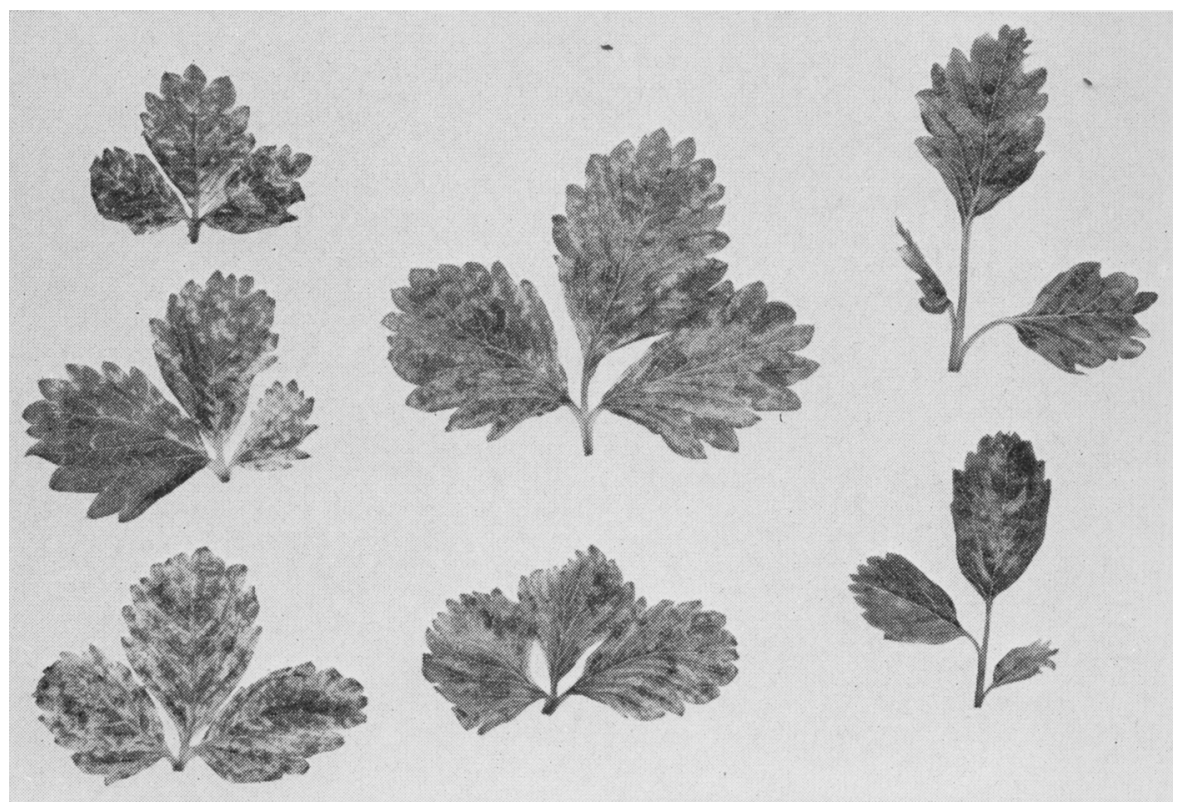

Fig. 7. Leaves from Alpine plants infected with curly-dwarf mottle virus isolate 1: left, first leaves, and center, second leaves to develop symptoms; right, during chronic stage of disease. (Berkeley)

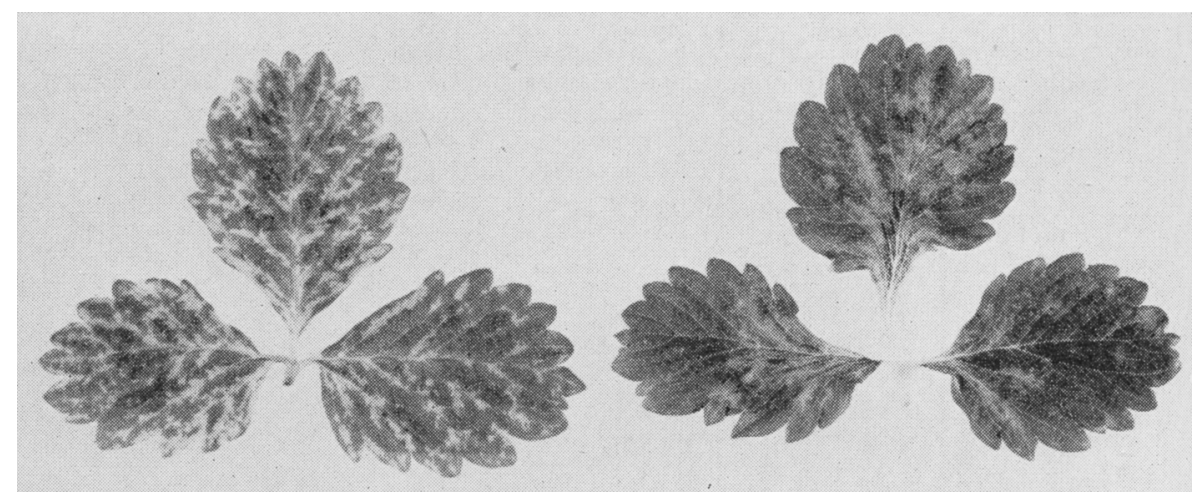

Fig. 8. Leaves from Alpine plants infected with curly-dwarf mottle virus isolate 3 showing: left, primary symptoms; right, chronic symptoms of infection. (Berkeley) 


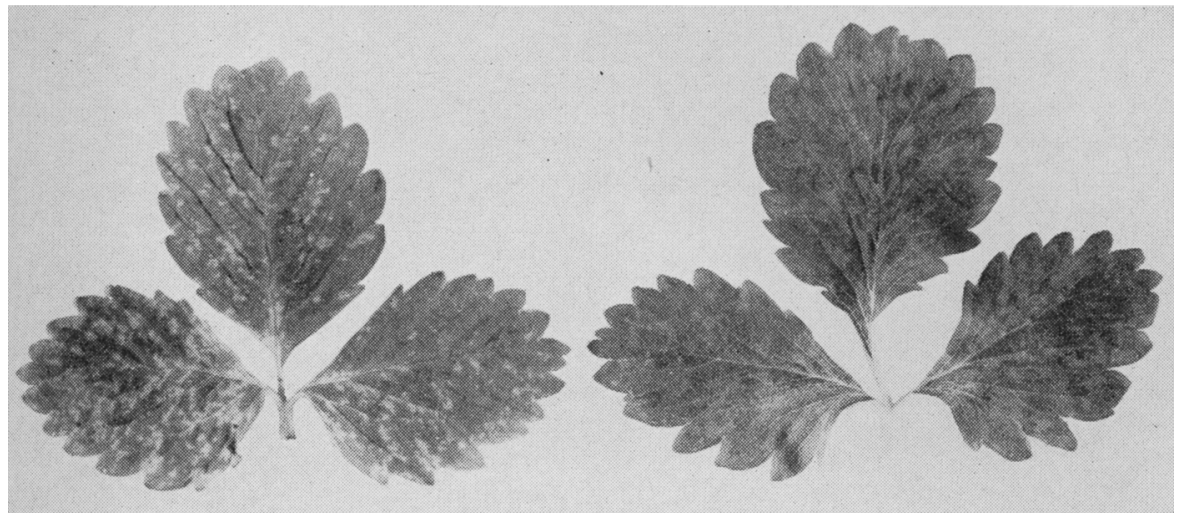

Fig. 9. Leaves from Alpine plants infected with curly-dwarf mottle virus isolate 4 showing: left, primary symptoms; right, chronic symptoms of infection. (Berkeley)

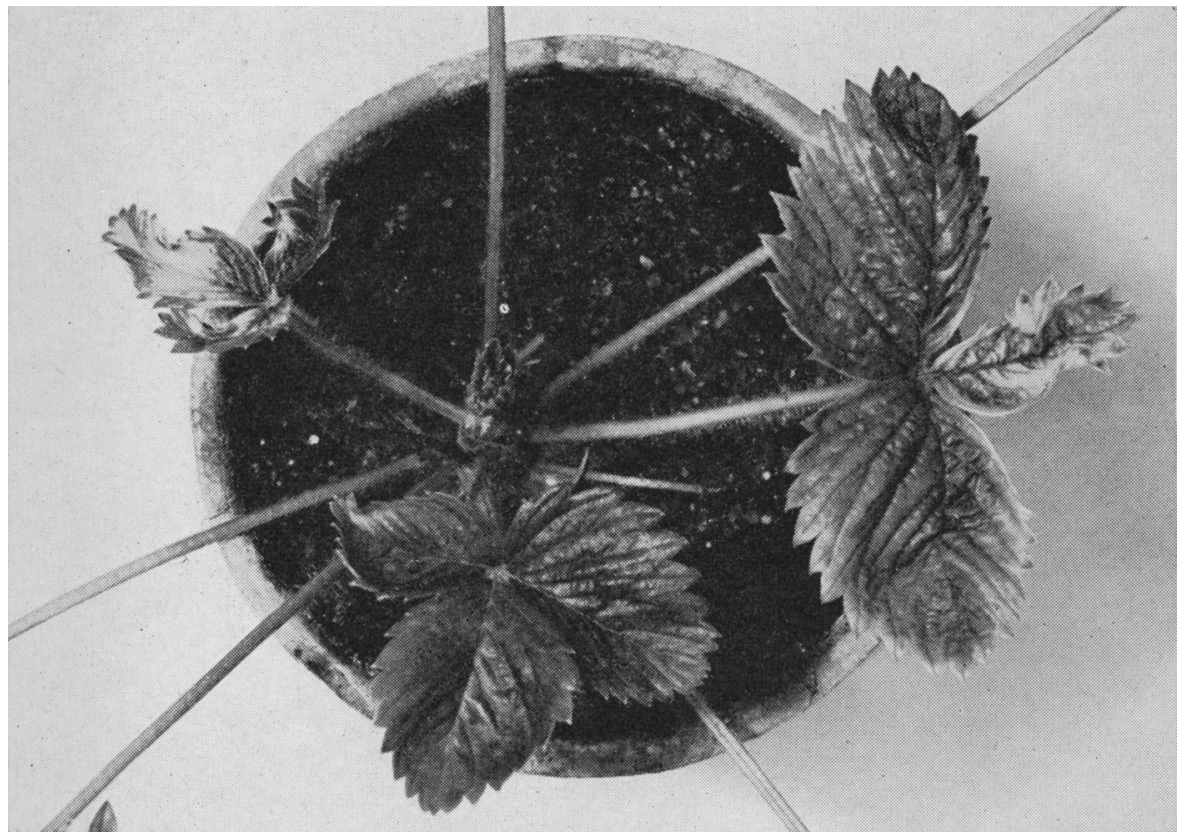

Fig. 10. Plant of a UC-1 indicator clone infected first with latent-A virus and later with rusty-leaf mottle virus showing early symptoms of the double infection. (East Malling) 


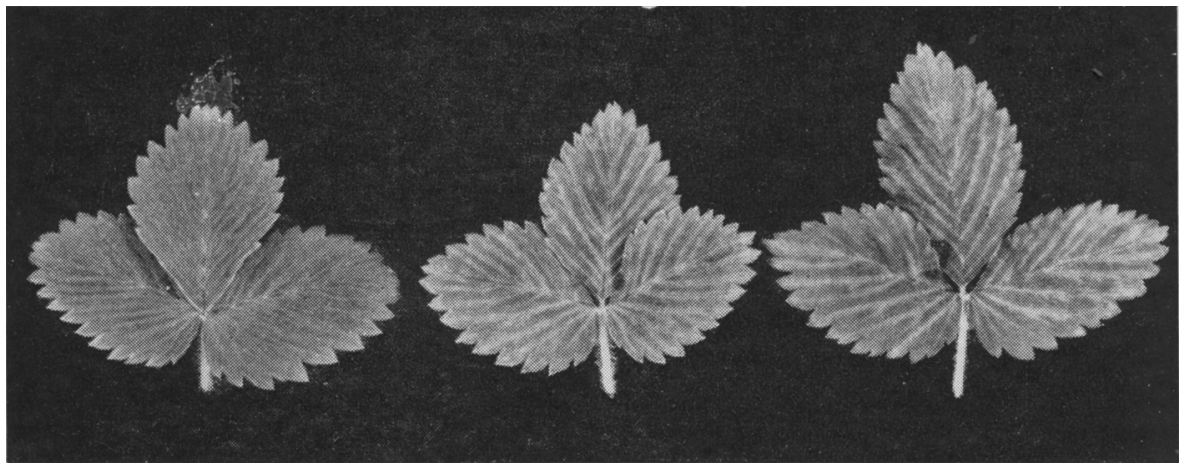

Fig. 11. Leaves from UC-1 indicator plants chronically infected with leaf-curl virus. (East Malling)

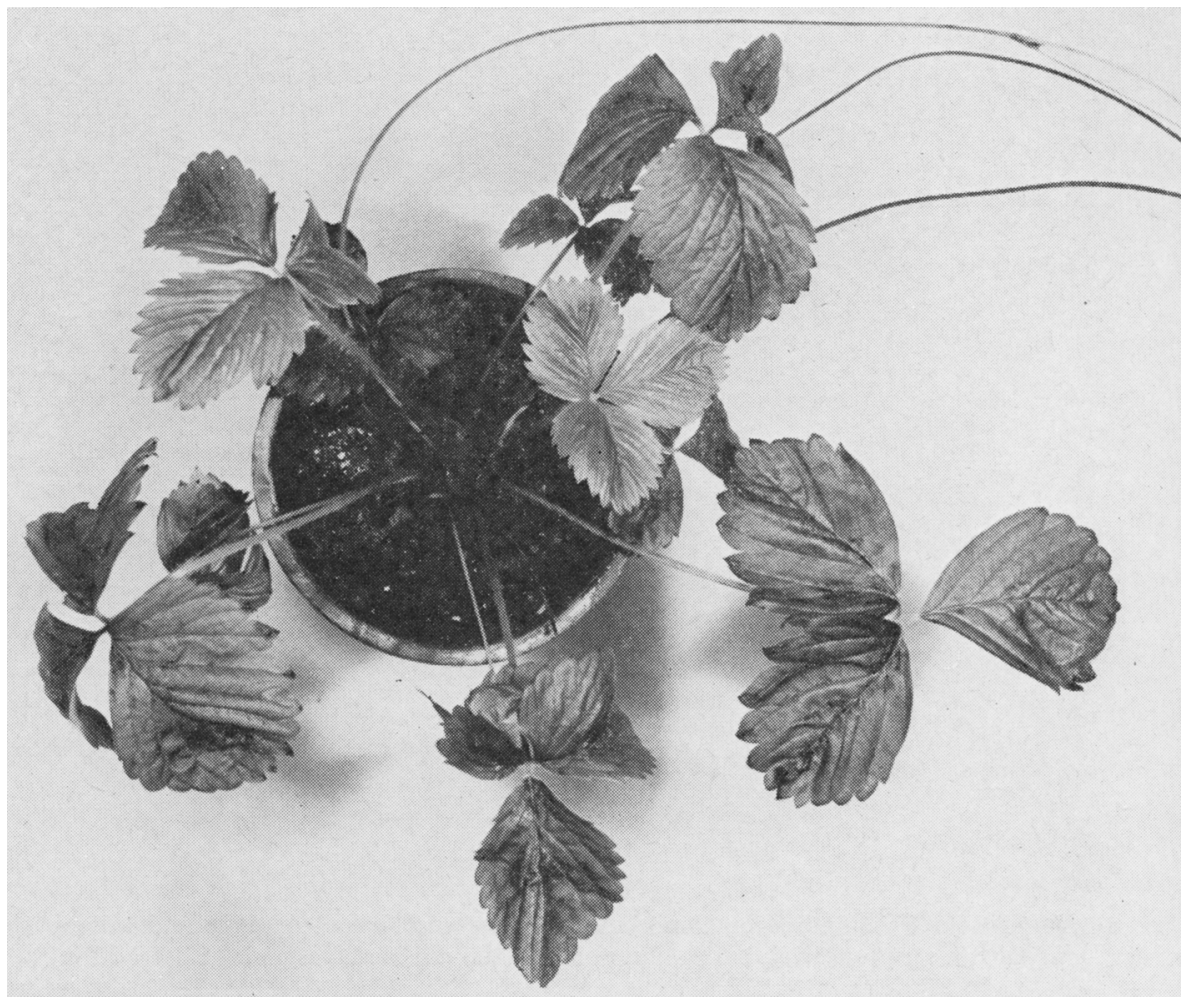

Fig. 12. EMC indicator plant showing symptoms of the leaf-curl disease complex resulting from double infection with latent-A and leaf-curl viruses. (East Malling) 


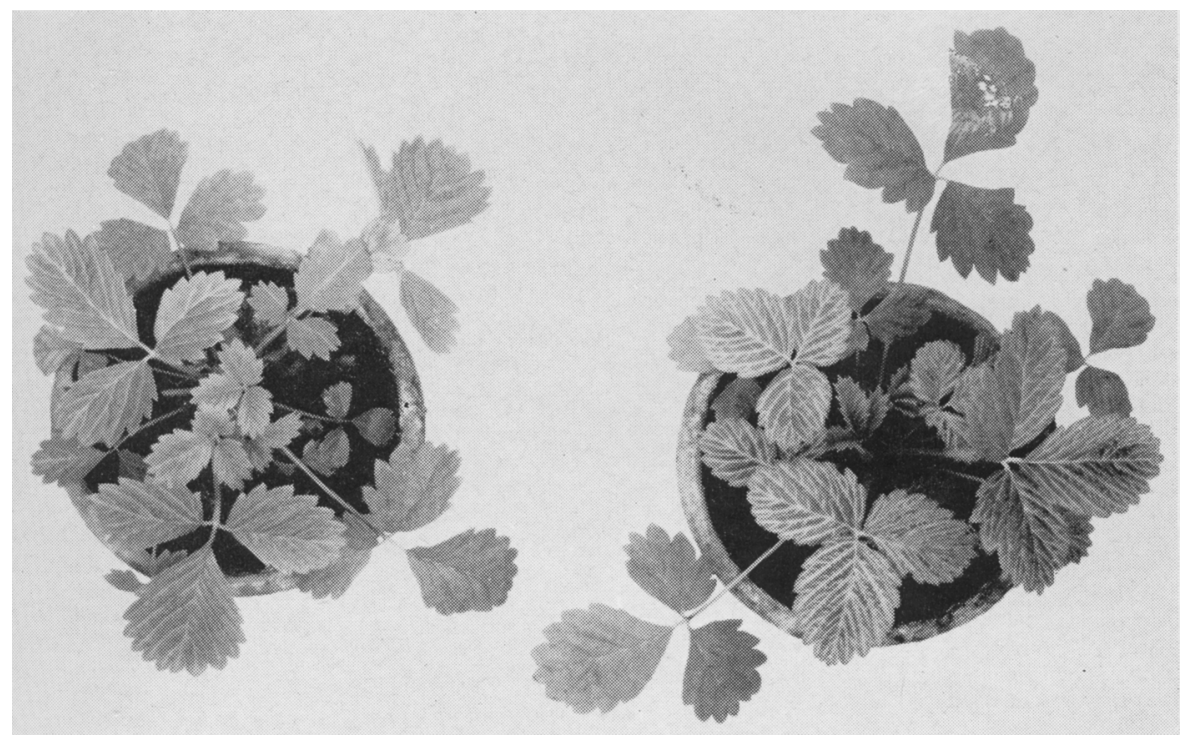

Fig. 13. Alpine plants during early stage of infection with: left, yellow vein banding virus; right, vein banding virus. (Berkeley) 


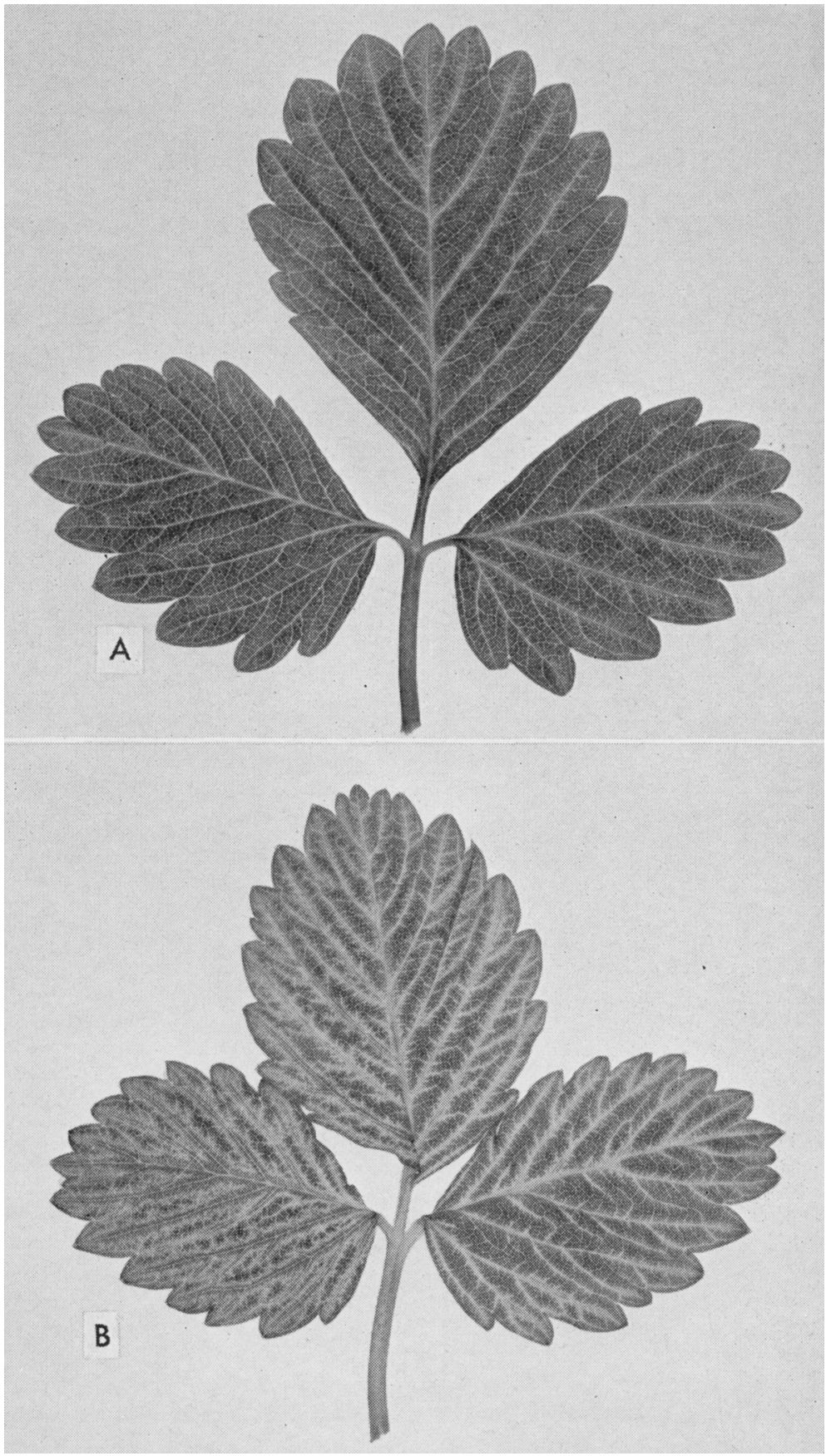

Fig. 14. Leaves from Alpine plants showing first symptoms of infection with: (A) yellow vein banding virus; $(\mathrm{B})$ vein banding virus. (Berkeley) 


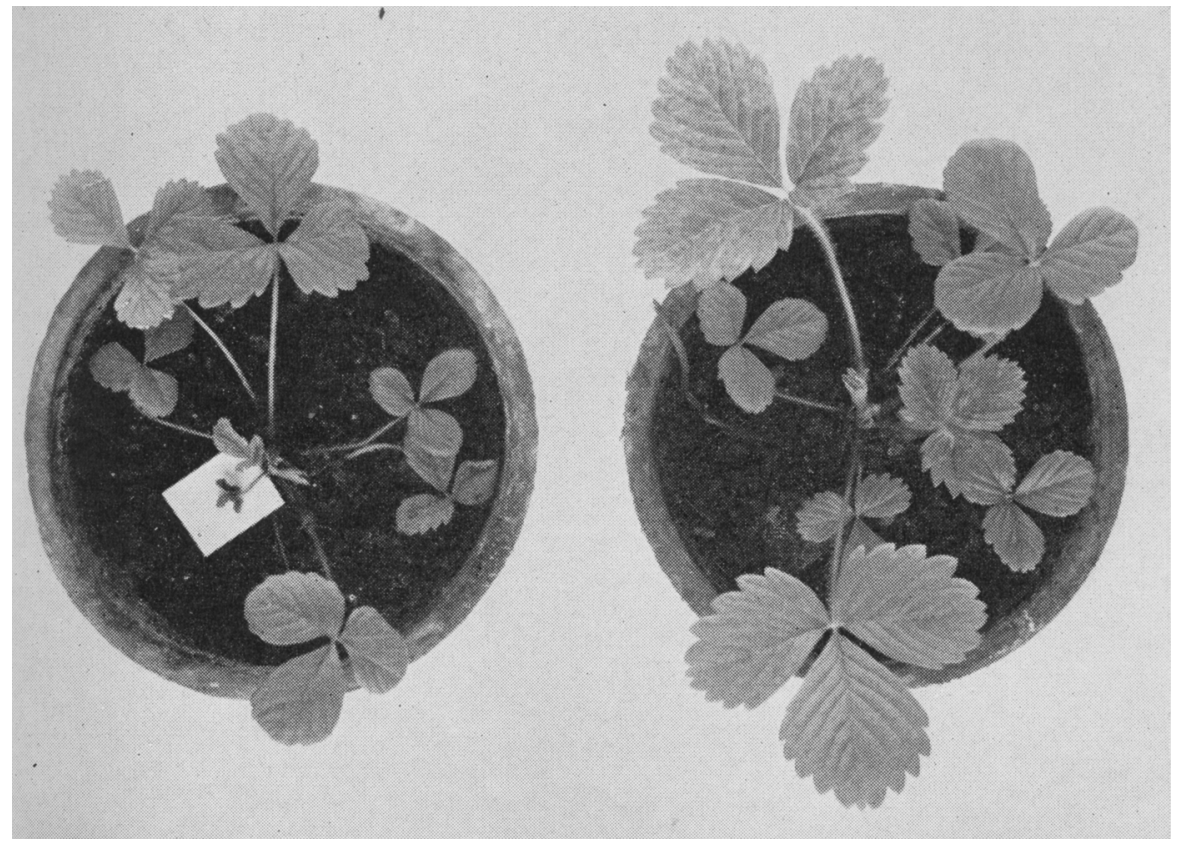

Fig. 15. Plants of a $F$. vesca seedling clone infected simultaneously with mottle virus isolate 1 at which time the plant on the left was already carrying latent-B virus while that on the right was virus free. Note the severe effect of the double infection on the plant to the left; the necrotic leaf on the white background and the leaf showing cleared veination at the upper center of the plant on the right were the first to develop symptoms of infection. (Berkeley)

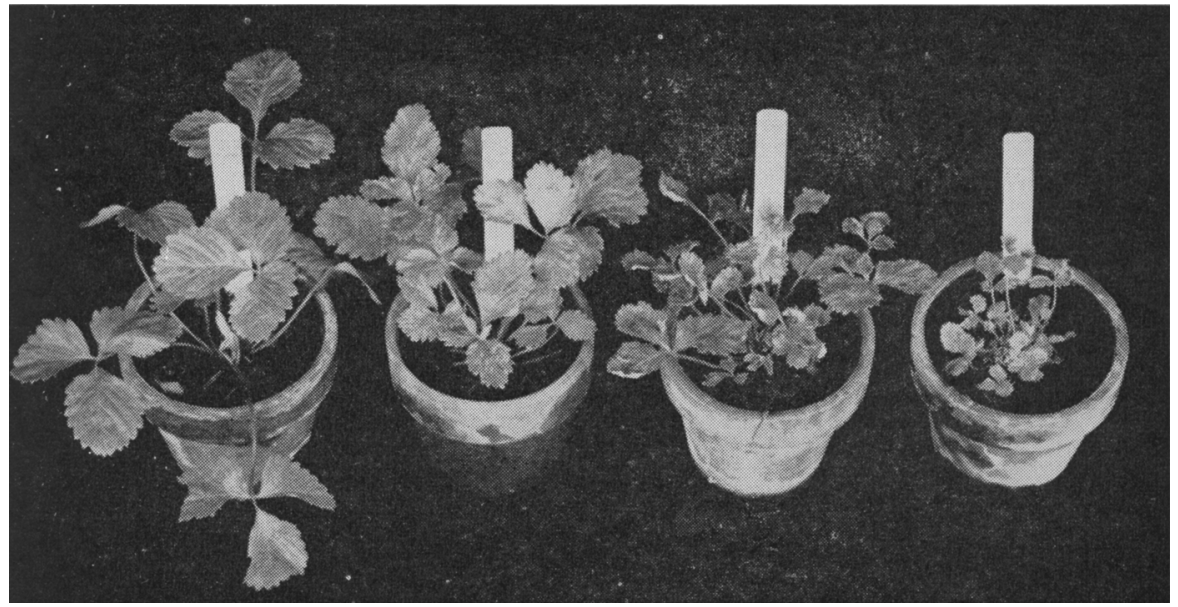

Fig. 16. UC-1 plants infected simultaneously with mottle virus isolate 2 but which were, at the moment of inoculation, from left to right respectively : virus free; already infected with latent-A virus; already infected with latent-B virus; already infected with a mild form of crinkle virus. (Berkeley) 


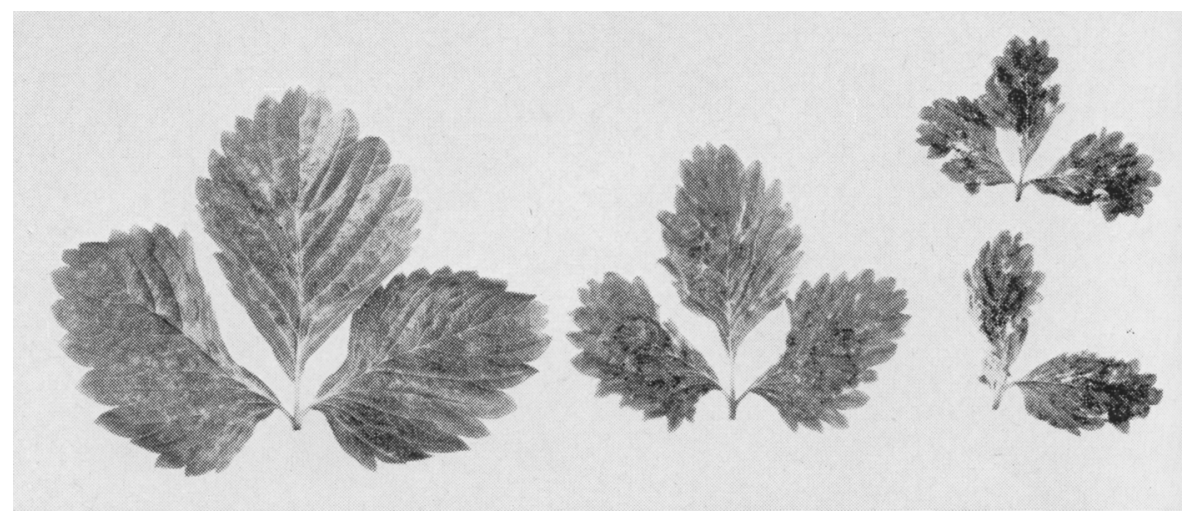

Fig. 17. Leaves from UC-1 plants showing chronic symptoms of infection with: left, mottle virus isolate 2 ; center, mottle virus isolate 2 and latent-A virus; right, mottle virus isolate 2 and latent-B virus. Note the chlorotic spots and tattered leaflet margins which characterize the symptoms of the double infections. (Berkeley)

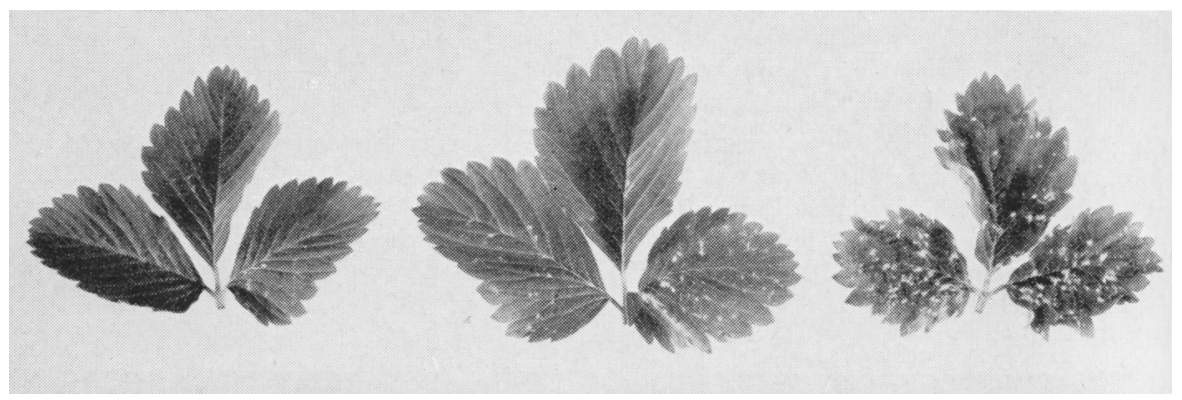

Fig. 18. Leaves from UC-1 plants showing chronic symptoms of infection with: left. latent-B virus; center and right, a mild and a severe isolate respectively of crinkle virus. (Berkeley) 


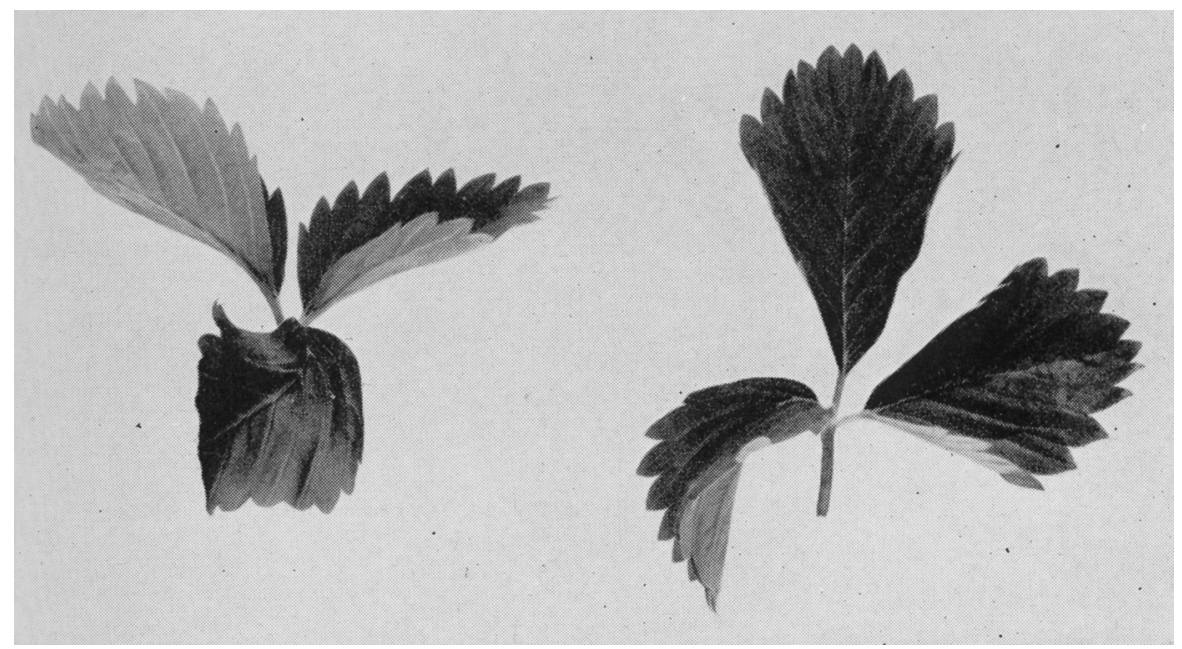

Fig. 19. Leaves from UC-1 plants, each with a backward, angularly-bent leaflet, a primary symptom of infection with lesion-A virus. (Berkeley)

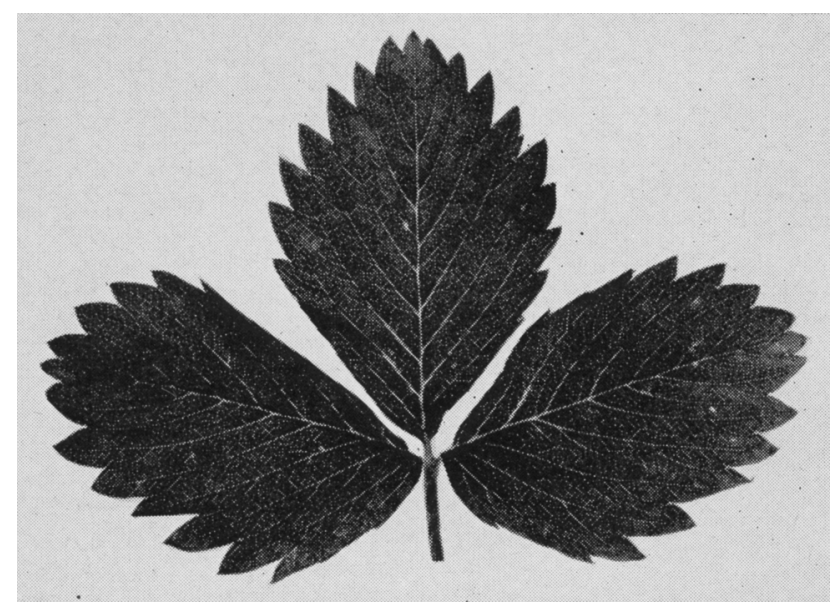

Fig. 20. Leaf from UC-1 plant infected with lesion-B virus showing ineonspicuous chlorotic vein spotting. (East Malling) 


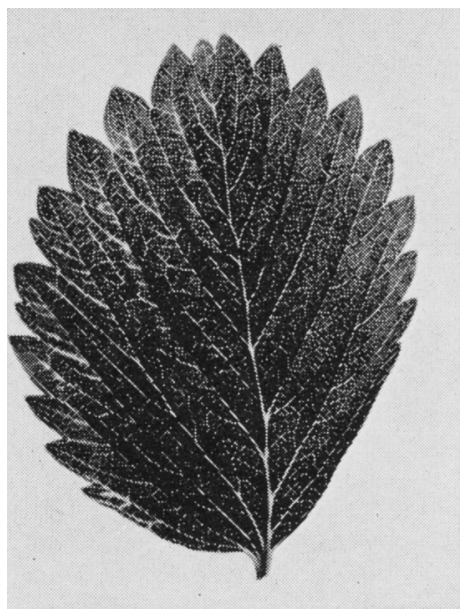

Fig. 21 Leaflet from an East Malling clone $F$. vesca plant infected with latent-A and vein chlorosis viruses showing slight vein yellowing. (East Malling)

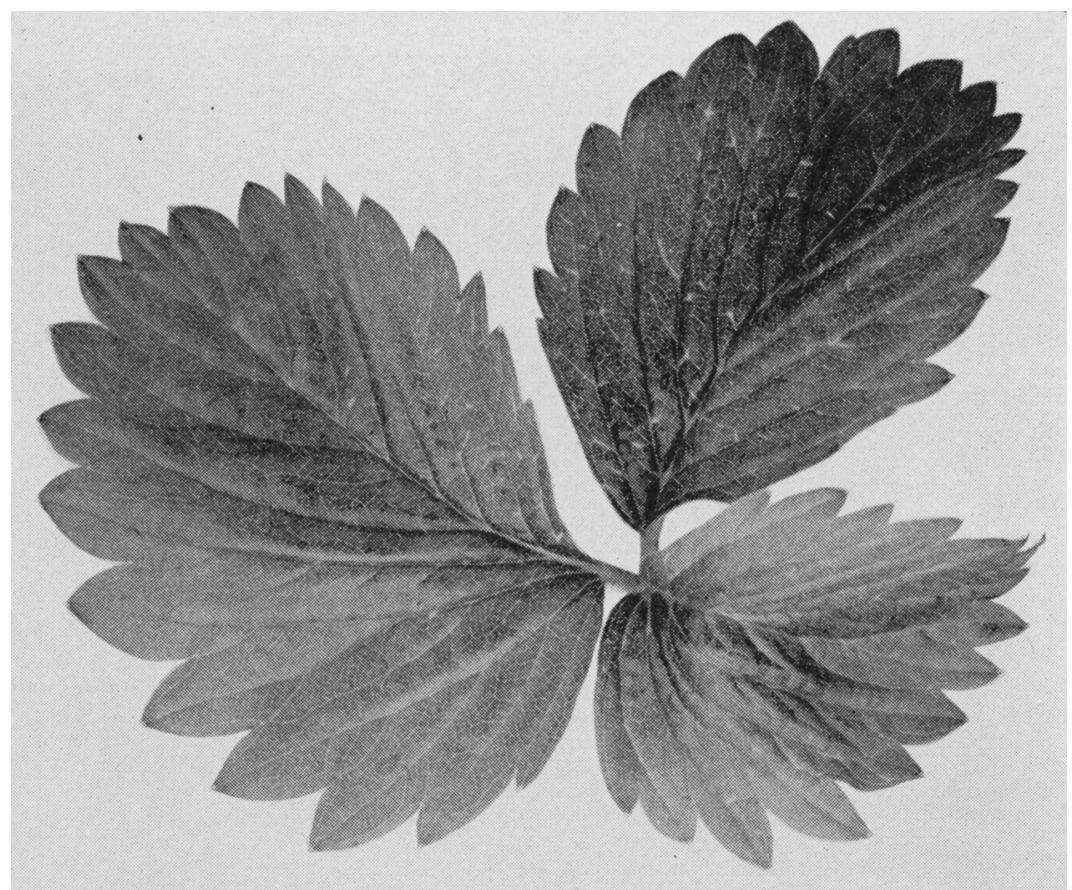

Fig. 22. Leaf from a UC-1 plant during first stage of infection with crinkle virus showing chlorotic vein flecking and angular backward bending of leaflets. (Berkeley) 


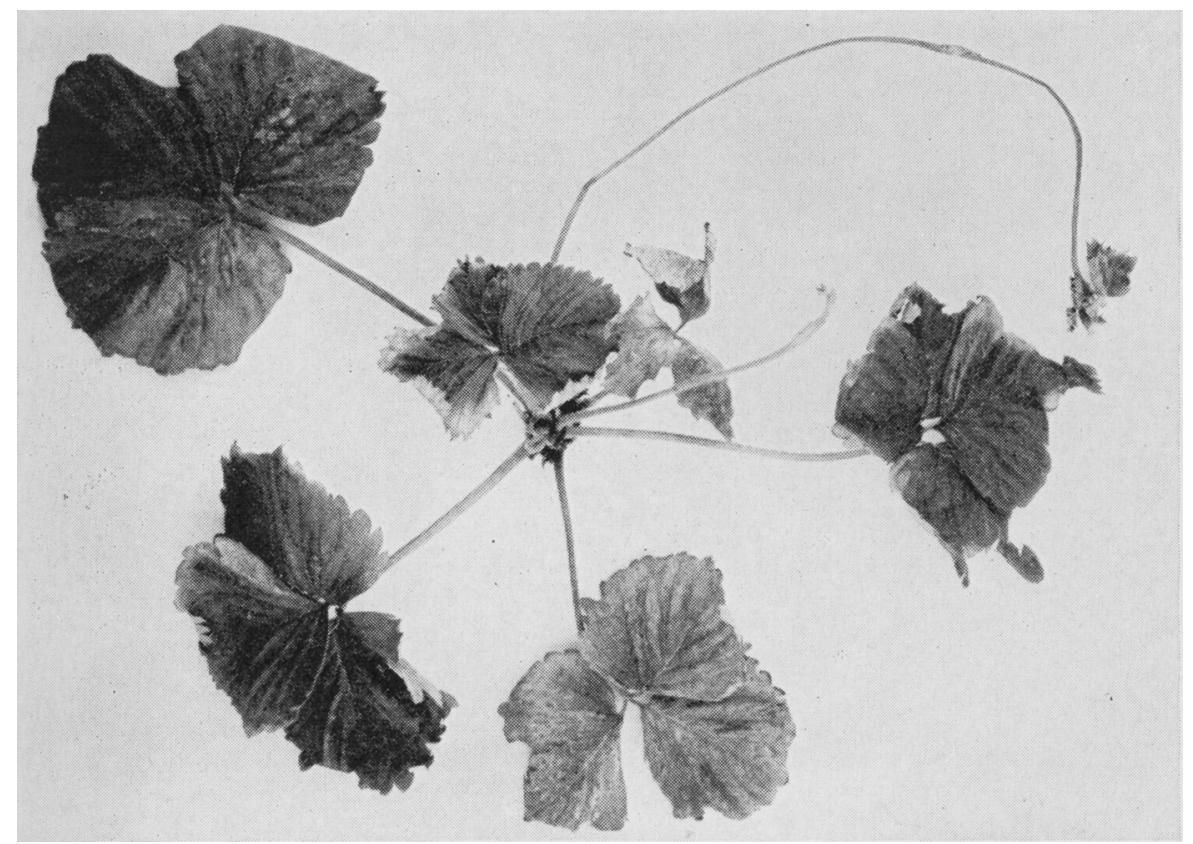

Fig. 23. Shasta plant naturally infected with aster yellows virus with scalded leaves and necrotic crown. (Berkeley) 


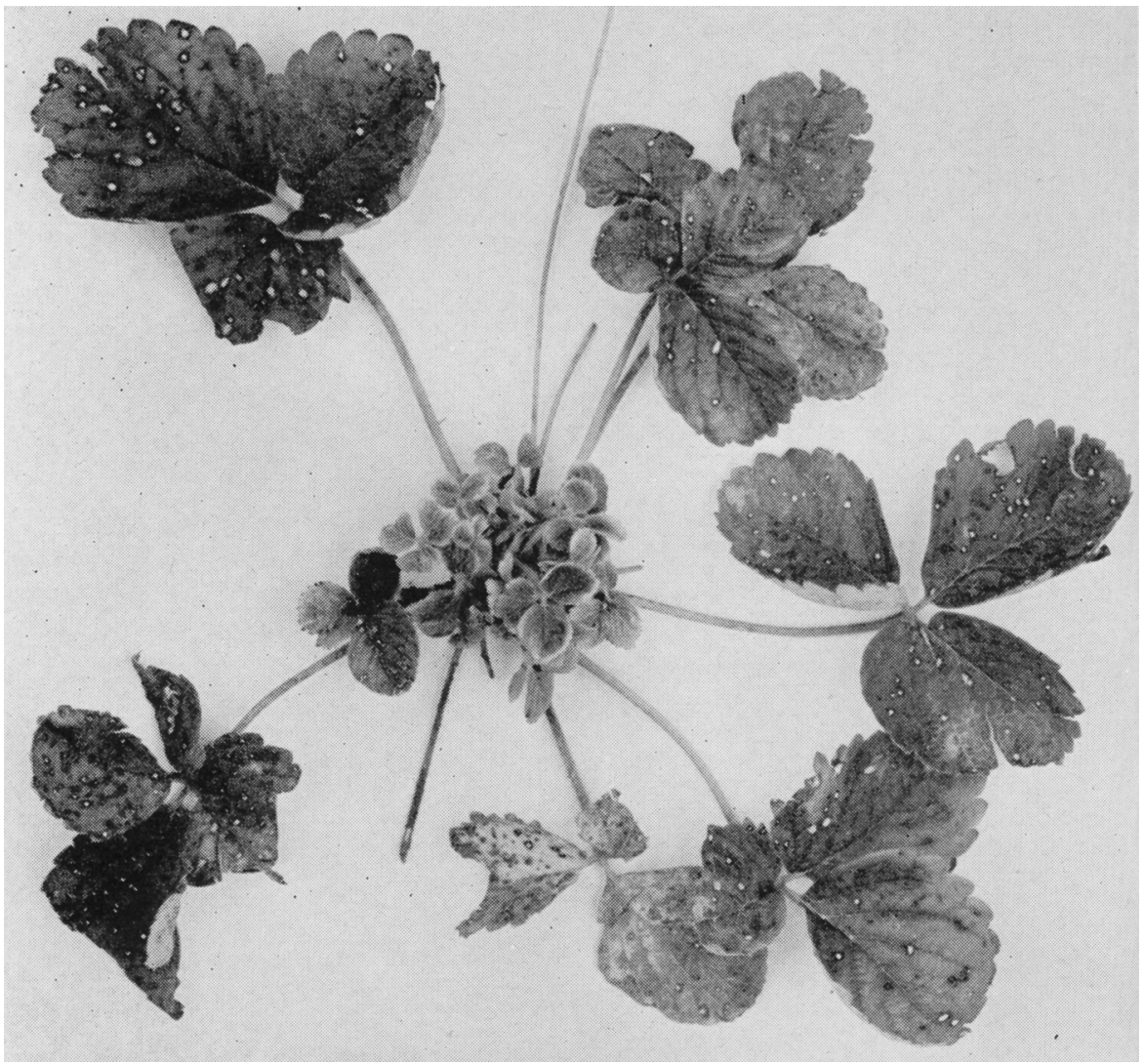

Fig. 24. Plant of a commercial hybrid seedling clone naturally infected with aster yellows virus; note the proliferation of dwarf, chlorotic, cupped leaves. (Berkeley) 


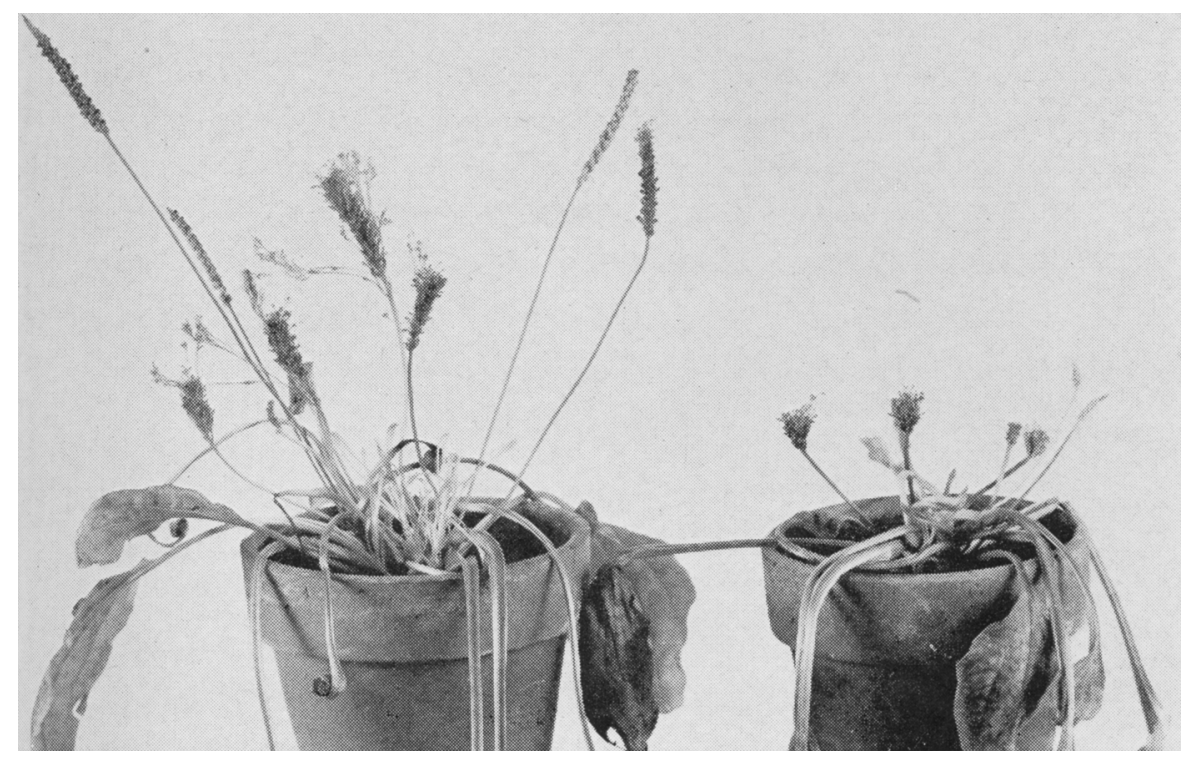

Fig. 25. Broad-leaved plantain infected with aster yellows virus from: left, a stock glass house culture; right, a naturally infected strawberry plant. (Berkeley)

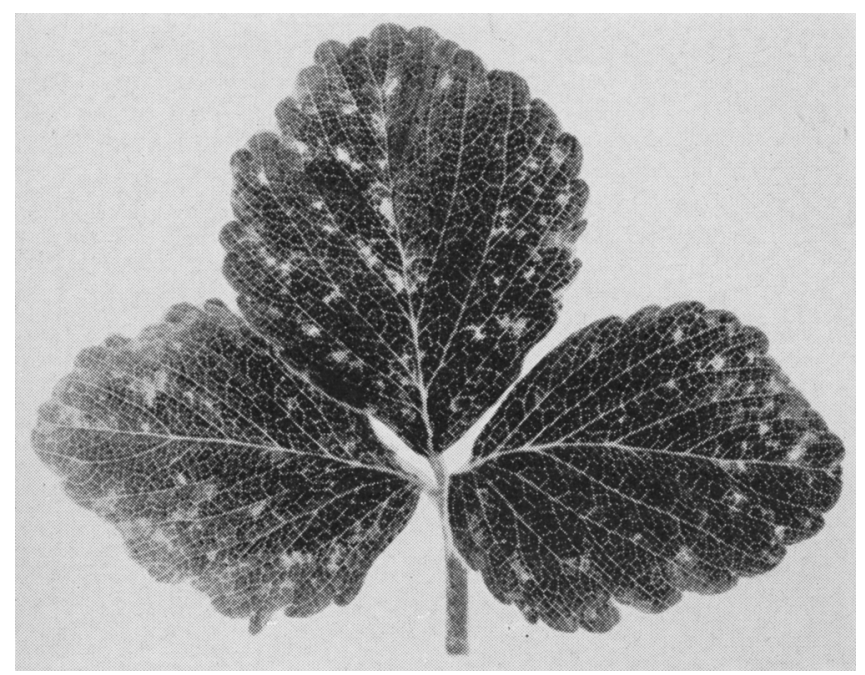

Fig. 26. Symptoms of raspberry yellow dwarf virus in a leaf of Cambridge Favourite strawberry. (East Malling) 
The journal Hilgardia is published at irregular intervals, in volumes of about 600 pages. The number of issues per volume varies.

Subscriptions are not sold. The periodical is sent as published only to libraries, or to institutions in foreign countries having publications to offer in exchange.

You may obtain a single copy of any issue free, as long as the supply lasts; please request by volume and issue number from:
Agricultural Publications
Room 22 Giannini Hall
University of California
Berkeley 4, California

The limit to nonresidents of California is 10 separate issues on a single order. A list of the issues still available will be sent on request. 